\title{
Breast cancer osteomimicry and its role in bone specific metastasis; an integrative, systematic review of preclinical evidence.
}

\author{
Olugbenga Awolaran ${ }^{1}$, Susan A Brooks ${ }^{2 *}$, Verna Lavender ${ }^{1}$
}

Department of Applied Health and Professional Development ${ }^{1}$ and Biological and Medical Sciences ${ }^{2}$, Oxford Brookes, University, Gipsy Lane, Headington, Oxford, OX3 0BP, UK.

*corresponding author

Email sbrooks@brookes.ac.uk

Tel $+44(0) 1865483285$

\begin{abstract}
Metastasis accounts for most of the deaths from breast cancer and the preference of invasive breast cancer metastasising to bone has been widely reported. However, the biological basis of breast cancer osteotropism is not fully understood. This paper provides, for the first time, an integrative, systematic review of evidence of molecular factors that have functional roles in the homing of metastatic breast cancer to the bone.
\end{abstract}

Pubmed, Web of Science and EBSCOhost were searched using keywords and synonyms for molecular, metastasis, breast cancer and bone to identify articles published between January 2004 and August 2016. 4,491 potentially relevant citations were retrieved. 63 articles met the inclusion criteria, which were primary studies reporting evidence of molecular factors that have functional roles in predisposing breast cancer bone metastasis in vivo.12 of those 63 articles that additionally met quality criteria were included in the review. Extracted data were tabulated and key findings that indicated biological mechanisms involved in breast cancer metastasis to bone were synthesised. 
15 proteins expressed by breast cancer cells were identified as factors that mediate breast cancer bone metastasis: ICAM-1, cadherin-11, osteoactivin, bone sialoprotein, CCN3, IL-11, CCL2, CITED2, CXCR4, CTGF, OPN, CX ${ }_{3}$ CR1, TWIST1, adrenomedullin and Enpp1. Upregulation or overexpression of one or more of them by breast cancer cells resulted in increased breast cancer metastasis to bone in vivo, except for CCL2 where bone-metastatic cells showed a reduced expression of this factor. All factors identified, here expressed by breast cancer cells, are proteins that are normally expressed in the bone microenvironment and linked to physiologic bone functions. All have a functional role in one of more of the following: cell proliferation and differentiation, bone mineralization and remodeling, cell adhesion and/or chemokine signaling. Six of them (cadherin-11, ICAM-1, OPN, $\mathrm{CX}_{3} \mathrm{CR} 1$, CCN3 and osteoactivin) have a reported function in cell adhesion and another eight (CCN3, osteoactivin, Enpp1, IL-11, CTGF, TWIST1, adrenomedullin and CITED2) are reported to be involved in cell proliferation and differentiation.

This review collates and synthesises published evidence to increase our understanding of the biology of breast cancer osteomimicry in the development of bone metastasis. Findings of this review suggest that changes in expression of proteins in breast cancer cells that confer ostemimicry facilitate homing to bone to enable the development of bone metastasis.

\section{Key words}

Breast cancer, metastasis, bone, osteomimicry

\section{Highlights}

- 15 proteins were identified as factors that promote breast cancer bone metastasis

- Expression of these factors by breast cancer cells mediate osteotropic metastasis 
- All factors identified are proteins that are normally expressed in the bone microenvironment

- Breast cancer cell protein expression conferring ostemimicry facilitates osteotropic metastasis 


\section{Introduction}

Paget suggested that cancer cells are more likely to metastasize to a tissue that has the necessary components to support their growth, just as a seed would only grow in soil in which it can thrive [1]. This concept implies that cancer cells migrate to environments that are biologically favourable for colonisation in terms of growth factor production, receptor expression and other stromal characteristics, such as tissue origin. If this 'seed and soil' theory were always true one would expect that cancers in paired organs, like breast and kidney, would commonly metastasise to the contralateral organ. However, clinical evidence indicates that metastases rarely form in a contralateral paired organ. Furthermore, there is a $98 \%$ chance that a breast cancer in the contralateral breast is due to a second, unrelated primary tumour [2].

Ewing proposed, in contrast, that metastatic site specificity was purely mechanical; the first organ that tumour cells passed via blood circulation was the most likely site of metastasis owing to their physical entrapment there [3], as in the example of breast cancer metastases forming in the lungs. However, a large volume of blood from breast tissue also passes through the heart and spleen and breast cancer metastases rarely form in these organs [4]. Evidently, beyond the anatomical exposure to cancer cells, there seems to be a requirement for host-tumour compatibility and specific interaction for metastasis to occur. Hence Paget's theory of related biological factors is, on balance, more favoured [5].

Bone is the commonest and often the earliest site of distant metastasis in breast cancer [6]; $50 \%$ of individuals newly diagnosed with advanced breast cancer have bone metastases, compared to $30 \%, 26 \%$ and $7 \%$ with liver, lung, brain metastases, respectively [7]. About $70 \%$ of women who die from breast cancer have bone metastases [8], which is where the majority of the tumour burden resides at the time of death [2].

Breast cancer metastases characteristically cause osteolytic lesions, though osteoblastic tumours are found in $25 \%$ of cases [2]. There is a growing body of evidence that breast 
cancer cells interact with bone stroma facilitating the process of metastasis [9]. For example, breast cancer cells secrete parathyroid hormone related peptide (PTHrP), which stimulates osteoblasts to produce RANKL. This in turn activates osteoclasts, which create osteolytic lesions, and consequently release growth factors stimulating further growth of the breast cancer cells that produce more PTHrP; hence a vicious cycle of positive feedback develops [9].

Osteoclast resorption of the bone has been described as a key characteristic that creates a favourable environment for tumour growth. During resorption, osteoclasts secrete proteolytic enzymes that degrade the bone matrix and release abundant growth factors, cytokines and chemokines, all of which attract circulating tumour cells and support their growth [10]. Bussard and colleagues [11] suggested that the continuous bone turnover, together with the resultant release of chemotactic and trophic factors, could explain site specificity of bone metastasis in most cancers, including breast cancer. However, despite such metastatic favourability, bone metastases are very rare in some other common solid tumours, such as colorectal cancers [7]. This suggests that beyond the growth promoting environment in bone, a significant level of specific interaction is required between cancer cells and bone tissue for bone metastases to establish successfully.

A systematic search of relevant databases for review papers concerning breast cancer metastasis to bone identified those focusing on the bone as a common site of metastasis for many cancers [11-13] and factors involved in breast cancer metastasis to different host organs $[6,14]$. One review that specifically evaluated factors involved in breast cancer metastasis to the bone was found [8]; however, no systematic reviews were identified. Therefore, herein, for the first time, we report an integrative, systematic review of molecular factors that are shown to have functional roles in homing of metastatic breast cancer to the bone. 


\section{Method}

\section{Literature Search}

A systematic search of articles published in English between January 2004 and September 2016 was conducted in the electronic databases Pubmed ${ }^{\circledR}$, Web of Science ${ }^{\mathrm{TM}}$ and EBSCOhost using keywords and synonyms for molecular, metastasis, breast cancer and bone to search 'all terms'. Boolean operators and truncations of keywords were employed to both expand and restrict the search. Search expansion was performed using citation chaining in Web of Science ${ }^{\mathrm{TM}}$ and snowballing of reference lists of articles that met inclusion criteria. Using this method only one article published prior 2004 was identified that met the inclusion criteria for this review.

\section{Inclusion and exclusion criteria}

Studies that reported primary research findings about molecular factors that have a functional role in breast cancer bone metastasis were included in this review. Included studies were also deemed to have been ethically conducted, for example ethical approval was reported in the study, and met defined quality criteria, as follows. Included studies were designed prospectively with a focus on bone as a metastatic site from breast cancer. Studies entirely carried out in vitro without in vivo testing were excluded in order to ensure that findings included in the review considered the role of the tumour microenvironment. Studies using bone tropic models that specifically demonstrated osteotropic effects of specific gene products were included. This was because the review aimed to identify evidence about gene products that exerted osteotropic effects in breast cancer. The same genes may have additional roles in metastasis, including enabling metastasis to develop in tissues other than bone, but those effects were not the focus of this study, so data about additional putative roles were not extracted as part of this review. Studies that focused on assessing experimental techniques, clinical data, or therapeutic testing were also excluded. The 
inclusion and exclusion process is depicted in an adapted PRISMA flow chart adapted from Moher et al [15] (Figure 1).

\section{Exclusion process}

Initially citations were screened by OA at the level of the title and then abstract by OA and VL for relevance using parameters set by the inclusion and exclusion criteria. Citations that met or potentially met inclusion criteria at the level of the title and abstract were obtained in full text for further assessment against the inclusion and exclusion criteria. Potentially relevant sources were independently reviewed in full by OA and VL for internal validity. In addition, full texts of all studies included in the review were assessed by OA and SB for eligibility against the inclusion criteria.

\section{Quality appraisal}

Studies obtained in full text that met the inclusion criteria were assessed for quality by OA and SB using a checklist for critiquing scientific research described by Kuyper [16]. Studies were assessed to identify whether the following criteria were appropriate and reliable, and clearly reported: title, study aims, study design and method (e.g. in vivo, cell lines, animal model), and reporting of results. Details of the quality appraisal for each included study are shown in Table 1. Authors' conclusions were also appraised to assess whether they reflected the findings of the study and whether any limitations of the study were identified within the publications reviewed. Studies that met the quality criteria described above were included in the review. The strength of evidence presented by the studies was also assessed in order to judge their significance in contributing to the review and thus identify the strengths and limitations of the review (Table 1).

\section{Data extraction}

Data were independently extracted and tabulated by OA and SB in order to aggregate, sort, compare and integrate findings [17]. Extracted data were author and publication date; 
functional factors identified; wild type function of molecular factor(s) (if known); main findings from each study; and interpretation of study findings (Table 2).

\section{Integrative synthesis}

The wildtype functions of factors that were found to be associated with breast cancer cells preferentially metastasising to bone tissue were analyzed to consider putative molecular mechanisms that facilitate breast cancer cells metastasising to bone tissue. From the aggregated data extracted from the studies reviewed, functional factors were integrated by grouping into categories according to their primary wildtype function. The categories were further analysed as a whole (akin to data synthesis) by constructing a diagram of wildtype function grouping (Figure 2).

\section{Results}

\section{Retrieval and exclusion process}

The search results and exclusion process is illustrated in a PRISMA flow-diagram (Figure 1). From 4,491 citations initially retrieved, after rigorous exclusion, 63 full-text articles were assessed for relevance, of which 11 reported primary research that fully met inclusion criteria for the review. For example, potentially relevant studies that were excluded from the review reported roles in the development of lung metastasis, but did not demonstrate the preferential formation of metastases in bone tissue. An additional study published prior to 2004, which was one of those pioneering the use of in vivo selection to develop bone seeking breast cancer clones and gene profiling of the cells [18], was included in the review due to its seminal relevance. 
Fig.1 PRISMA flow-diagram of search results and exclusion process, after Moher et al [15]

\section{Quality appraisal}

Quality appraisal confirmed that all studies included in the review stated clear aims and were designed prospectively. All included both in vitro and in vivo approaches using established breast cancer cells lines to identify factors associated with the formation of breast cancer colonies in bone tissue of inoculated mice, Table 1 and references therein.

All studies described the use of appropriate and rigorous controls. Control methods were carefully assessed to ensure clear the distinction between experimental samples and control samples. In most of the studies reviewed, the controls were breast cancer cell lines that had poor affinity to metastasize to the bone, or high affinity to metastasize to tissue other than bone.

All studies reported evidence of functional roles for specific molecular factors in the homing of breast cancer cells to bone tissue. Nine of the studies reported robust evidence classified as 'strong' or 'moderate', Table 1; they consistently demonstrated correlation between expression of specific proteins and the development of bone metastasis using a variety of techniques and experimental models.

\section{Findings from functional studies}

Overall, 15 factors that were associated with breast cancer cells homing to bone tissue were reported in the reviewed studies, Table 2 and references therein. Eleven studies reported factors that were over-expressed in clones of bone-homing breast cancer cell lines, while one study [23] reported a factor (CCL2) that was associated with increased bone metastasis when it was down-regulated. Findings were mapped onto a diagram by function, illustrating factors and possible molecular mechanisms involved in bone metastasis, Figure 2. 
Intercellular adhesion molecule-1 (ICAM-1 or CD5) and cadherin-11 (OB (osteoblast)cadherin) were highly overexpressed in both human (MDA-MB-231BO) and murine (4T1E/M3) bone metastasizing cancer cells [21,22]. Rose et al [20] reported a correlation between endogenous osteoactivin overexpression and the formation of bone lesions in multiple cancer cell lines (4T1 cells, its selected bone metastatic population, 590, 592, 593, $606 \mathrm{BM} 2$ and non-bone metastatic 67NR and 66cl4). Increase in bone metastases in immunocompetent mice inoculated with cancer cells $(66 \mathrm{cl})$ bearing exogenously expressed osteoactivin was also shown. CITED2 (CREB-binding protein (CBP)/p300 interacting transactivator with glutamate (E) and aspartate (D) tail 2) was expressed at high levels in sublines of mouse NT2.5 cells that had high bone metastatic potential compared to those that had low bone metastatic potential; in addition, knockdown of CITED2 resulted in a reduction in bone metastasis [24].

The expression of chemokine receptor $\mathrm{CX}_{3} \mathrm{CR} 1$ was significantly increased in cancer cells that promote breast cancer bone metastasis in vivo (MDA-MB-231), compared to expression levels in cells (MDA-MB-436) that have a weak affinity to metastasize to bone [26]. Exogenous overexpression of CX3CR1 in a breast cancer cell line with weak affinity to form bone metastasis resulted in a 3-fold increase in bone metastatic tendency. Furthermore, introduction of $\mathrm{CX}_{3} \mathrm{CR} 1$ positive cells into mice null for its binding partner, fractalkine, resulted in a significant reduction in bone, but not adrenal, metastases.

Kang et al [18] reported a 4-fold overexpression of CXCR4 in selected bone metastatic clones of MDA-MB-231 compared to the parent population, which appeared to have a synergistic effect with other co-expressed osteogenic genes (interleukin 11, osteopontin (OPN) and connective tissue-derived growth factor (CTGF)) on the formation of bone metastasis. 
A relationship between exogenous overexpression in breast cancer cell lines and the ability of the cell line to form bone lesions in vivo was also reported. Zhang et al [19] exogenously overexpressed bone sialoprotein (BSP) in breast cancer cells that exclusively formed brain lesions in vivo (MDA-MB-231-BR), and found overexpression of BSP resulted in $100 \%$ of the metastatic lesions forming in bone, and not brain, tissue. Expression of CCN3 (also known as nephroblastoma overexpressed (NOV)) in breast cancer cells was associated with increased bone metastasis [25]. This indicated a functional role, which was investigated by transfecting CCN3 into a weakly bone metastatic cancer cell line $(66 \mathrm{cl} 4)$, which doubled the bone affinity of this cell line when inoculated into mice. Siclari et al (2014) [29] reported that when adrenomedullin was over-expressed five-fold by MDA-MB-231 cells and inoculated into immunodeficient mice, they formed osteolytic bone metastases more rapidly than untransfected cells. Moreover, cells over-expressing adrenomedullin formed larger tumours when injected into mammary fat pads. Expression of TWIST1 has also been reported to enhance the ability of an osteotropic subclone of MDA-MB-231 cells to form osteolytic lesions [28]. A greater number of micrometastases were established, radiographically detectable lesions were were $50 \%$ larger than those formed by mock-transfected cells, and more extensive bone destruction was seen. Suppression of TWIST1 abolished the effect.

One factor expressed in breast cancer cells was reported to have an inhibitory role in the formation of bone metastatic lesions. CCL2 (chemokine C-C ligand 2, also known as monocyte chemo-attractant protein 1 - MCP-1) expression was shown to be down regulated in bone-specific cancer cells (4T1E/M3) and its overexpression reduced the bone metastatic potential of the cancer cells [23]. Another factor appeared to have an osteolytic function. Lau et al. [27] reported higher levels of Enpp1 (ectoenzyme ectonucleotide pyrophosphatase/phosphodiesterase I) expression in bone seeking human and murine cancer cell lines (MDA-MB-231/MDA-MB-468 and NT2.5, respectively). MDA-MB-231 cells transfected with Enpp1 had an increased rate of destruction/loss of bone density, compared to non-transfected cells. 


\section{Discussion}

Here we present, for the first time, a systematic review of molecular factors that have putative roles in the homing of breast cancer cells to bone. This is a novel method for reviewing primary research from molecular biology experiments, and involves conducting a systematic search, applying pre-defined inclusion and exclusion criteria, using standard criteria to appraise the quality of the findings, and systematically sorting findings. The method used in this review has been adapted from established systematic review methods used to address medical, health and social science research questions [30-32]. A systematic approach to the review enabled secondary analysis of extracted findings as an integrated data set. It also facilitated independent review of published findings by members of the research team (akin to a process of internal peer review) following a pre-determined, standardized method, which we argue increases the validity and reliability of data synthesis.

This review describes fifteen proteins that were found to be associated with breast cancer cells having an affinity to metastasise to bone, which was dependent on their expression levels. The wildtype function of these proteins includes cell adhesion and motility, osteoblast proliferation and differentiation, mineralisation of bone extracellular matrix, and chemokine activity. These factors demonstrated preferential and potent bone tropic function. It is worth noting that this finding does not exclude functional roles in the development of metastasis to other tissue types and the factors described in this review may also have roles in the formation of metastases in tissue sites additional to bone.

Six of the fifteen molecular factors identified here have a reported function in cell adhesion (cadherin-11, ICAM-1, OPN, $\mathrm{CX}_{3} \mathrm{CR} 1, \mathrm{CCN} 3$ and osteoactivin, Figure 2) and all were shown to promote bone metastasis when overexpressed in breast cancer cells. Cadherin-11 is a calcium dependent cell adhesion protein particularly expressed in osteoblasts [33]. ICAM-1 is a transmembrane structural protein, but can also exist in soluble form in plasma as sICAM-1. It is abundantly expressed on the surface membrane of leukocytes and endothelial 
cells where it exerts its primary function in adhesion of leukocytes to the vascular endothelium, but its expression can also be induced in other cells during inflammatory processes [34]. ICAM-1 is also expressed on osteoblast and osteoclast precursor cells in the bone microenvironment. It mediates osteoclastogenesis and subsequent bone resorption by facilitating osteoblast RANK receptor and osteoclast RANKL ligand leading to osteoclast formation [35]. Osteopontin (OPN) has many reported functions, amongst them is osteoclast adhesion to bone matrix $[36,37] . \mathrm{CX}_{3} \mathrm{CR} 1$, a chemokine receptor, is involved in leukocyte adhesion and migration during the immune response [38]. The secretory protein CCN3 found in bone extracellular matrix also functions in cell adhesion [25,39]. Osteoactivin, a transmembrane protein found on osteoblasts and osteoclasts plays a regulatory role in endothelial cell adhesion [40].

Eight of the fifteen factors identified in this review (CCN3, osteoactivin, Enpp1, IL-11, CTGF, CITED 2 and TWIST1, adrenomedullin, Figure 2) are reported to be involved in cell proliferation and differentiation. CCN3 [39], along with transmembrane proteins osteoactivin [40] and Enpp1 [41], have wildtype functions in osteoblast differentiation. Osteoactivin is also involved with osteoclast formation [40] and Enpp1 also generates pyrophosphate, which is a source of phosphate for bone mineralization, found to be involved in pathologic calcification of non-bone tissues [41]. IL-11 is involved in osteoclast formation from bone marrow progenitor cells [42], and CTGF in osteoblast formation; both are responsive to transforming growth factor beta (TGF- $\beta$ ) signaling [18]. CITED2 is a transcriptional co-activator that positively regulates TGF- $\beta$ signaling and is activated by hypoxia inducible factor $1 \alpha$ (HIF-1 $\alpha$ ) [43]. In addition to increased expression of the extracellular matrix (ECM) protein CCN3 and mineralizing protein Enpp1 in bone seeking cells, this review also found bone seeking behavior by cells exogenously overexpressing the non-collagenous ECM glycoprotein BSP $[44,45]$. TWIST1 is a transcription factor that regulates cell motility and tissue reorganization during embryogenesis [46]. It is reactivated in many cancers where it is involved in epithelialmesenchymal transition (EMT) facilitating cancer intravasation and metastasis and in 
avoidance of senescence and apoptosis [46,47]. Adrenomedullin expression is induced by hypoxia. It has complex and widespread homeostatic function including bronchodilation, vasodilation, angiogenesis, lymphangiogenesis, hormone secretion and is involved in inducing apoptosis and cell proliferation, including osteoblast proliferation [48].

Fig.2 Functional roles of identified factors and possible molecular mechanisms involved in bone metastasis

Most published evidence regarding molecular factors with functional roles in breast cancer bone metastases formation identifies cell adhesion, cell differentiation and extracellular matrix proteins, consistent with the findings outlined above. However, this review also identified putative evidence for the role of chemokine signaling when co-expressed with other factors (Figure 2). CCL-2 overexpression reduced bone metastatic potential, however, there was still some level of bone metastasis recorded, signifying that other contributing factors may be involved in this process [23]. CCL2, a chemokine, is a strong chemotactic agent for monocytes, and is expressed in a wide variety of tissues. It has putative roles in both macrophage-facilitated angiogenesis and tumour growth inhibition [49]. $\mathrm{CX}_{3} \mathrm{CR} 1$ is a Gprotein coupled chemokine receptor that is found abundantly in osteoblasts and its ligand, CX3CL1 (or fraktalkine), is produced by bone marrow stromal cells $[26,50]$. CXCR4 is a chemokine receptor involved in both bone marrow homing and extravasation [18, 51]. Osteopontin is a multifunctional adhesion factor with lymphokine function that stimulates osteoclast adhesion to bone matrix $[18,52]$.

A striking observation about most of the factors identified in this review is that their wildtype pattern of expression and function is in the bone microenvironment maintaining normal bone physiology. It appears that some breast cancer cells are able to mimic osteogenic cells by switching on the expression of osteogenic genes [53]. The intrinsic bone regulating 
characteristics of healthy breast cells in breast tissue development [54] and lactation [55] might confer such osteomimicry in malignant breast cells. In addition to osteomimicry in breast cancer cells that form bone metastases, there is evidence of osteomimicry in other osteotropic cancers, for example prostate [56] and lung cancers [57]. This suggests a role for factors in the tumour microenvironment that is common in osteotropic cancers.

Osteomimicry is thought to promote both homing of cancer cells to bone tissue and their survival in the bone microenvironment [58], which might also explain why these cells metastasise to the bone in preference to the contralateral organ, or other remote organs and tissues. The gene products described herein could be classified using Nguyen and Massague's classification of 'metastasis virulence' genes [59]. Proteins expressed by metastasis virulence genes are proposed to direct selective colonization of secondary sites by exerting functions, such as capillary adhesion, extravasation and organ specific colonization [59]. The review suggests that Paget's 'seed and soil' theory of cancer cells forming metastatic colonies in microenvironments that are favourable to their growth [1] holds true.

\section{Strengths and limitations of the review}

We have described the methods we used to conduct a comprehensive, systematic search strategy in an attempt to retrieve all relevant literature accessible via electronic databases since 2004 and associated snowballing and citation chaining. A pre-defined, standardized method of inclusion, exclusion, data extraction and analysis were used to identify integrate and synthesise findings of the review, which provides transparency in reporting, and we believe adds validity and reliability to conducting a literature review.

All of the reviewed studies investigated osteotropism of breast/mammary cancer cell lines in vivo using a murine model of metastasis, which enabled modeling within the context of tumour microenvironments within whole organisms. All studies either reported that ethical permission had been obtained or described work that indicated it was conducted in an 
ethical manner. However, Zhang et al [19], while stating that their study was approved by their Institutional Animal Care and Use Committee (University of Texas Health Center at San Antonio, USA) and was performed in accordance with NIH Guide for the Care and Use of Laboratory Animals, describe how tumour bearing animals became crippled and suffered bone fractures, which raises cause for concern.

Studies on human breast cancer cells used immunodeficient (athymic nude, neu-N and SCID) mice to prevent the rejection and immunologic killing of the inoculated human cells by the murine immune system, while those using murine mammary tumour cells employed immunocompetent (BALB/c mice) mice. Each approach has its strengths and limitations. While the use of immunodeficient mice allows the study of metastasis of human breast cancer cells in a non-human host, it does so in the absence of immune response factors that themselves might be functionally important to metastasis. The use of immunocompetent mice addresses that issue, but murine mammary tumours differ fundamentally from human breast cancer in many aspects of their metastasis. In almost all studies reviewed here, highly artificial techniques were used to create circulating breast cancer cells, which were introduced into the mice by either intracardiac, tail vein or intratibial injection, thus modeling, at best, only the late stages of metastasis, once the cancer cells are already blood-borne, or lodged within bone. Only Takahashi et al [23] attempted subcutaneous implantation, and their study resulted in relatively weak evidence of bone metastasis-specific factors. Croset et al [28] performed xenograft experiments, injecting cancer cells into the mammary fat pad, but only in order to assess primary tumour growth. In this study, metastasis was achieved through tail artery injection.

There is also the issue that cell lines themselves are limited in their ability to reflect the complexities of clinical cancer biology. It is interesting that a limited range of cancer cell lines were used in the studies reported here. MDA-MB-231 were employed in all eight studies that used human breast cancer cell lines, sometimes in combination with one or more other of MDA-MB-468 and MDA-MB-436. In those studies that used murine mammary cancer cells, 
4/6 studies employed $4 \mathrm{~T} 1$ cells and their metastatic variants. This resulted in highly homogeneous tumour formation and the limitation that data are being derived from a very narrow model which, potentially, may not accurately reflect the clinical situation. Whilst useful for investigating functional gene expression, this does not reflect the highly heterogeneous profile of most metastatic human breast cancers. In addition, bone metastases develop more commonly from estrogen receptor (ER) positive than ER negative breast cancers [60]; however several cell lines used in the reviewed studies lacked ER expression, for example MDA-MB-231 and 4T1 [61]. It would therefore be preferable for studies investigating the bone metastatic properties of breast cancer cells to employ ER positive cell lines, such as the human MCF-7 cell line. There are, therefore, many obvious limitations in these well used and accepted model systems. Overall, these methodological factors need to be taken into consideration when interpreting research findings, as they may cause experimental artefacts that do not accurately model natural processes.

Different experimental approaches were used in the studies reviewed, including genomics, transcriptomics and proteomics, and findings from studies that used multiple techniques to explore the functional role of a given molecular factor might be regarded as providing more convincing evidence. In several studies, microarray analysis of highly bone metastatic breast cancer clones identified tens to hundreds of genes that were overexpressed or underexpressed $[18,23,24]$, however further in vitro and in vivo testing was only reported for $1-4$ of these genes, and the criterion for selecting these genes was generally not described or was vague. Such selection of subsets of samples creates a potential for bias, which we recognise might be reflected in the review.

\section{Clinical implications}

Bone metastases from breast cancer cause significant morbidity and mortality. Currently, there are no diagnostic techniques that enable reliable detection of bone micrometastases at 
the time of diagnosis. Instead breast cancer bone metastases are commonly diagnosed following presentation of a symptom, such as pain. Bone targeted agents, bisphosphonates $[62,63]$ and denosumab (Xgeva®, Amgen) $[63,64]$, are effective for reducing pain and delaying time to the first skeletal related event (SRE) (pathological fracture, spinal cord compression, bone radiation or bone surgery) in people with advanced breast cancer $[65,66]$. Serious adverse events that lead to discontinuation of bone targeted therapies include hypocalcaemia, impaired renal function and osteonecrosis of the jaw [67]. Best supportive care and palliative symptom control also have a role in reducing the risk of SRE and reducing pain in cases where bone targeted agents are contraindicated, for example impaired renal function [68]. Although interventions for treating bone metastases are effective in managing symptoms and delaying SRE, the majority of bone-targeted therapy trials have not been shown to improve overall survival of people with bone metastatic breast cancer [65].

An eminently preferable strategy to palliating symptoms of bone metastases or delaying SRE would be to prevent the development of bone metastases in the first instance. One approach might be to use adjuvant treatment targeting factors that promote breast cancer cells metastasising to the bone prior to the formation of bone metastasis, which has been explored in mouse models in several studies reported here $[21,24,26]$. However, much work is yet to be done to achieve this outcome in humans, since it requires a robust body of evidence to indicate the role of a molecular factor expressed in early breast carcinogenesis that later confers bone metastatic character, development of molecular diagnostic techniques to determine which tumours present a risk of forming bone metastasis, and subsequent development of effective targeted therapies that are clinically tolerable. Clinical correlation between the presence of the functional factors identified in this review in primary tumours in patients and either poor clinical outcome or, in some instances, specifically the presence of bone metastases, provides evidence that they may represent promising targets for such further endeavor. Some instances of such evidence are summarized below. 
In the study by Jamieson-Gladney et al [26] identified in this review, in addition to the animal model work described previously, the authors also performed immunohistochemistry to detect $\mathrm{CX}_{3} \mathrm{CR} 1$ on tissue arrays of human breast cancer and normal breast tissue samples. They reported a low level of $\mathrm{CX}_{3} \mathrm{CR} 1$ immunopositivity in normal breast and an increase in intensity and distribution of immunopositivity in breast cancers, a finding that is consistent with the authors' previous work on prostate cancer [69]. Here, in addition, bone marrow was shown to contain soluble $\mathrm{CX} 3 \mathrm{CL} 1 /$ fractalkine, which is released from bone marrow cells upon androgen stimulation, thus suggesting a potential role in bone tropism. Similarly, in the study by Lau et al (2013) [27] included in this review, the authors assessed human clinical samples alongside their animal studies. Comparing both mRNA levels and Enpp1 immunolabelling of clinical samples, they demonstrated that Enpp1 was overexpressed in primary breast cancer compared to normal breast epithelium, and that the highest levels were observed in breast cancer metastases to bone. The same group [24] took a similar approach to their work highlighting CITED2 as potentially relevant to breast cancer osteotropsim. Again, in addition to the animal experiments discussed in this review, the authors examined clinical samples of primary invasive ductal carcinoma and bone metastasis samples and found levels of CITED2 mRNA to be elevated in both in comparison to normal breast epithelium. Moreover, levels in bone metastases were significantly higher than in primary tumours.

Bone sialoprotein has been detected in primary breast cancers [70,71] and clearly associated with development of bone metastases [72], which are also BSP-positive [73], and poor survival [74]. Osteopontin overexpression is also established as being associated with metastasis, although not specifically to bone, in many types of cancer [reviewed by 75,76 ]. Differential osteopontin expression has been detected in breast cancer samples [77] and plasma osteopontin levels have been clinically correlated with the presence of bone metastases and with survival rates in prostate cancer patients [78]. TWIST1 expression by primary breast cancers is associated with more clinically aggressive disease and poor 
survival [79] and is detectable in breast cancer cells that remain in the bone marrow following chemotherapy [80]. Adrenomedullin is expressed by many type of cancer [reviewed by 81 ]. Around $80 \%$ of breast cancers express adrenomedullin and high levels in the primary tumour and in the plasma predict lymph node metastases; a role in bone metastasis has been proposed [82]. IL-11 expression in primary breast cancer correlates with subsequent development of bone metastases [83]. CXCR4 has been implicated in the development of bone metastases in patients with neuroblastoma [84] and prostate cancer [85].

ICAM1 levels have been measured in the cytosol of breast cancer and benign breast tissue samples [86] and has been reported to induce a more invasive phenotype in breast cancer [87], but an association with bone metastasis in clinical studies has not specifically been explored. Osteoactivin is overexpressed in glioblastoma multiforme and is associated with poor clinical outcome and has been proposed as a potential molecular therapeutic target [88], although, again, association with bone metastasis specifically has not been reported. Cadherin-11 expression is well established as being associated with cancer cell invasiveness and epithelial mesenchymal transition (EMT). A recent meta-analysis of human cancer microarray datasets revealed that cadherin-11 is increased in breast ductal carcinoma in situ and breast cancer in comparison to normal breast epithelium, and is elevated in the stroma surrounding breast cancers compared to normal stroma [89]. Its association with metastatic competence has not been explored specifically. CCL2 has been detected in primary breast cancer samples [90], and ER-negative tumours have been reported to exhibit high levels of CCL2 expression [91]. In pancreatic cancer, patients with high serum CCL2 levels had a better prognosis than those with low levels [92], consistent with the findings reported in this review [23] that it is negatively associated with metastatatic competence.

CCN3 has diverse functional roles, which are context dependent. This complexity is reflected in conflicting reports of its significance in cancer biology. While CCN3 has been reported to exert growth-suppressive effects in several cancer types, paradoxically, it has also been 
shown to have a pro-migration and pro-metastatic role in melanoma [93] and Ewing's sarcoma [94] and high levels predict poor prognosis in prostate cancer [95], osteosarcoma [96] and renal cell cancer [97]. In breast cancer, reports have also been contradictory, with some reporting an association with good prognosis [98] and others reporting association with resistance to endocrine therapy [99]. In the study by Ouellet et al [25] reported in this review, in addition to the animal experiments, clinical samples of bone metastases from breast cancer were examined and strong CCN3 immunopositivity of tumour cells was seen in $50 \%$ of cases. Other studies have demonstrated high CCN3 positivity in bone metastases in comparison to metastases at other sites [100]. CTGF, also known as CCN2, is another member of the CCN family. Its presence in oral squamous cell carcinomas has been shown to be associated with local invasion of the mandible [101]. In hepatocellular carcinoma, intratumoral immunopositivity of the primary tumour biopsy for CTGF was predictive of bone metastases and, interestingly, combining intratumoral CTGF with IL-11, discussed previously, was an independent risk factor for bone metastases development [102]. In breast cancer, it is one of four genes (one of the others was osteopontin, discussed previously), that were identified as being overexpressed in bone metastases compared to disseminated tumour cells in the bone marrow that had not formed tumours [103] and was found to be overexpressed in primary breast cancers that had metastasised to bone as well as in the tumor cells of breast cancer bone metastases when compared to normal breast tissue [104].

\section{Implications for future research}

Further investigation is needed to elucidate molecular factors that have a functional role in enabling breast cancer cells to metastasise to bone tissue. Further experiments are specifically required to increase understanding of molecular interactions, signaling pathways, both upstream and downstream, of proteins identified in this review, which have putative functional roles in mechanisms of breast cancer bone metastasis. Prospective, longitudinal 
epidemiological studies, which include both exomic (sequencing the entire complement of exons) and proteomic analysis of tumour biopsies excised from cohorts of patients diagnosed with primary stage breast cancer, might identify additional important factors that have a functional role in the metastasis of breast cancer to bone.

\section{Conclusions}

We are still some distance from developing diagnostic techniques to identify primary breast cancers that have potential to metastasise to bone tissue, and specifically targeting such cells before the development of clinically apparent metastatic tumours. An important step in developing these techniques is increasing our understanding of the molecular mechanisms involved in these processes. In order to inform the development of future research on the topic, this systematic review integrates recent literature to identify molecular factors that have putative functional roles in the development of breast cancer bone metastases.

\section{Conflict of interest}

The authors declare that they have no conflict of interest.

\section{References}

1. Paget $\mathrm{S}$. The distribution of secondary growths in cancer of the breast. Lancet $1889 ; 1: 571-3$

2. Weinberg RA. The biology of cancer. $2^{\text {nd }}$ ed. New York: Garland science; 2014, p641-722

3. Ewing J. A treatise on tumours. $3^{\text {rd }}$ ed. Philadelphia: W.B. Saunders; 1928 
4. Zetter BR. The cellular basis of site-specific tumour metastasis. New England Journal of Medicine 1990;322:605-12

5. Gupta GP, Minn AJ, Kang Y, Siegel PM, Serganova I, Cordon-Cardo C, et al Identifying site-specific metastasis genes and functions. Cold Spring Harbor Symposia on Quantitative Biology 2005;70:149-58

6. Lu X, Kang Y. Organotropism of breast cancer metastasis. Journal of Mammary Gland Biology and Neoplasia 2007;12:153-62

7. Hess KR, Varadhachary GR, Taylor SH, Wei W, Raber MN, Lenzi R. Metastatic patterns in adenocarcinoma. Cancer 2006;106:1624-33

8. Guise TA, Kozlow WM, Heras-Herzig A, Padalecki SS, Yin JJ, Chirgwin JM. Molecular mechanism of breast cancer metastasis to the bone. Clinical Breast Cancer 2005;5:S46-53

9. Mastro AM, Gay CV, Welch DR, Donahue HJ, Jewell J, Mercer R, et al. Breast cancer cells induce osteoblast apoptosis: a possible contributor to bone degradation. Journal of Cell Biology 2004;91:265-76

10. Roodman GD. Mechanisms of bone metastasis. New England Journal of Medicine $2004 ; 350: 1655-64$

11. Bussard KM, Gay CV, Mastro AM. The bone micro enviroment in metastasis: what is special about the bone? Cancer and Metastasis Reviews 2008;27:41-55

12. Dougall WC, Chaisson M.The RANK/RANKL/OPG triad in cancer induced bone diseases. Cancer Metastasis Review 2006;25:541-49

13. Theriault RL, Theriault RL. Biology of bone metastasis. Cancer Control 2012;19:92101 
14. Lorusso G, Rüegg C. New insights into the mechanisms of organ-specific breast cancer metastasis. Seminars in Cancer Biology 2012;22:226-33

15. Moher D, Liberati A, Tetzlaff J, Altman DG, The PRISMA group. Preferred reporting items for systematic reviews and meta-analyses: The PRISMA Statement. PLoS Medicine 2009;6:e1000097

16. Kuyper BJ. Bringing up scientists in the art of critiquing research. Bioscience $1991 ; 41: 248-50$

17. Punch K. Developing effective research proposals. 2nd ed. London: Sage; 2006

18. Kang Y, Siegel PM, Shu W, Drobnjak M, Kakonen SM, Cordon-Cardo C, et al. A multigenic program mediating breast cancer metastasis to bone. Cancer Cell 2003;3:537-49

19. Zhang JH, Wang J, Tangi J, Barnett B, Dickson J, Hahsimoto N, et al. Bone sialoprotein promotes bone metastasis of a non-bone seeking clone of human breast cancer cells. Anticancer Research 2004;24:1361-68

20. Rose AAN, Pepin F, Russo C, Abou Khalil JE, Hallett M, Siegel PM. Osteoactivin promotes breast cancer metastasis to bone. Molecular Cancer Research $2007 ; 5: 1001-14$

21. Tamura D, Hiraga $T$, Myoui $A$, Yoshikawa $H$, Yonedi T. Cadherin-11 mediated interactions with bone stromal/osteoblastic cells support selective colonization of breast cancer cells in bone. International Journal of Oncology 2008;33:17-24

22. Takahashi M, Furihata M, Akimitsu N, Watanabe M, Kaul S, Yumoto N, et al. A highly bone marrow metastatic murine breast cancer model established in vivo selection 
exhibits enhanced anchorage-independent growth and cell migration mediated by ICAM-1. Clinical and Experimental Metastasis 2008;25:517-29

23. Takahashi M, Miyazaki $H$, Furihata $M$, Sakai $H$, Konakahara $T$, Watanabe $M$, et al. Chemokine CCL2/MCP-1 negatively regulates metastasis in a highly bone marrowmetastatic mouse breast cancer model. Clinical and Experimental Metastasis $2009 ; 26: 817-28$

24. Lau WM, Weber KL, Doucet M, Chou YT, Brady K, Kowalski J, et al. Identification of prospective factors promoting ostreotropism in breast cancer: a potential role for CITED2. International Journal of Cancer 2010;126:876-84

25. Ouellet V, Tiedemann K, Mourskaia A, Fong JE, Tran-Thanh D, Amir E, et al. CCN3 impairs osteoblast and stimulates osteoclast differentiation to favor breast cancer metastasis to bone. American Journal of Pathology 2011;178:2377-88

26. Jamieson-Gladney WL, Zhang Y, Fong AM, Meucci O, Fatatis A. The chemokine receptor CX3CR1 is directly involved in the arrest of breast cancer cells to the skeleton. Breast Cancer Research 2011;13:R91

27. Lau WM, Doucet M, Stadel R, Huang D, Weber KL, Kominsky SL. Enpp1: A potential facilitator of breast cancer bone metastasis. PLoS ONE 2013;8:e66752. doi:10.1371/journal.pone.0066752

28. Croset M, Goehrig D, Frackowiak A, Bonnelye E, Ansieau S,Puisieux A, et al. TWIST1 expression in breast cancer cells facilitates bone metastasis formation. Journal of Bone \& Mineral Research 2014;29:1886-99 
29. Siclari VA, Mohammad KS, Tompkins DR, Davis H, McKenna CR, Peng X, et al. Tumor-expressed adrenomedullin accelerates breast cancer bone metastasis. Breast Cancer Research 2014;16:458

30. Higgins JPT, Green S. (editors) Cochrane handbook for systematic reviews of interventions; 2011. Available at: http://handbook.cochrane.org/ (accessed: 10.11.15)

31. Centre for Reviews and Dissemination. Systematic Reviews. CRD's guidance for undertaking reviews in health care. CRD, University of York; 2009 ISBN: 1900640473 / ISBN13: 9781900640473

32. Dixon-Woods M, Agarwal S, Jones D, Young B, Sutton A. Synthesising qualitative and quantitative evidence: a review of possible methods. Journal of Health Services Research and Policy 2005;10:45-53

33. Berx G, van Roy F. Involvement of members of the cadherin superfamily in cancer. Cold Spring Harbor Perspectives in Biology 2009;1:a003129

34. Lawson C, Wolf S. ICAM-1 signaling in endothelial cells. Pharmacological Reports $2009 ; 61: 22-32$

35. Okada Y, Moromoto I, Ura K, Watanabe K, Eto S, Kumegawa M, et al. Cell to cell adhesion via intercellular adhesion molecule-1 and leukocyte function associated antigen-1 pathway is involved in $1 \alpha, 25(\mathrm{OH})_{2} \mathrm{D}_{3}, \mathrm{PTH}$ and IL-1 $\alpha$ induced osteoclast differentiation and bone resorption. Endocrine Journal 2002;49:483-95

36. Asou Y, Rittling SR, Yoshitake H, Tsuji K, Shinomiya K, Nifuji A, et al. Osteopontin facilitates angiogenesis, accumulation of osteoclasts, and resorption in ectopic bone. Endocrinology 2001;142:1325-32 
37. Denhardt DT, Giachelli C.M, Rittling SR. Role of osteopontin in cellular signaling and toxicant injury. Annual Review of Pharmacology \& Toxicology 2001;41:723-49

38. Imai T, Hieshima K, Haskell C, Baba M, Nagira M, Nishimura M, et al. Identification and molecular characterization of fractalkine receptor CX3CR1, which mediates both leukocyte migration and adhesion. Cell 1997;91:521-30

39. Ouellet V, Siegel PM. CCN3 modulates bone turnover and is a novel regulator of skeletal metastasis. Journal of Cell Communication and Signaling 2012;6:73-85

40. Sheng MHC, Wergedal JE, Mohan S, Lau KHW. Osteoactivin is a novel osteoclastic protein and plays a key role in osteoclast differentiation and activity. Federation of European Biochemical Societies (FEBS) Letters 2008;582:1451-58

41. Nam HK, Liu J, Li Y, Kragor A, Hatch NE. Ectonucleotide pyrophosphatase/phosphodiesterase-1 (ENPP1) protein regulates osteoblast differentiation. Journal of Biological Chemistry 2011;286:39059-71

42. Mangolas SC. Role of cytokines in bone resorption. Bone 1995;17:63S-67S

43. Chou YT, Wang H, Chen Y, Danielpour D, Yang YC. Cited2 modulates TGF- $\beta$ mediated upregulation of MMP9. Oncogene 2006;25:5547-60

44. Kruger TE, Miller AH, Godwin AK, Wang J. Bone sialoprotein and osteopontin in bone metastasis of osteotropic cancers. Critical Reviews in Oncology/Haematology 2014;89:330-41

45. Vincent K, Durrant MC. A structural and functional model for human bone sialoprotein. Journal of Molecular Graphics and Modelling 2013;39:108-17 
46. Ansieau S, Morel AP, Hinkal G, Bastid J, Pusieux A. TWISTing an embryonic transcription factor into an oncoprotein. Oncogene 201;29:3171-84

47. Ansieau S, Bastid J, Doreau A, Morel AP, Bouchet BP, Thomas C, et al. Induction of EMT by twist proteins as a collateral effect of tumor-promoting inactivation of premature senescence. Cancer Cell 2008;14:79-89

48. Bunton DC, Petrie MC, Hillier C, Johnston F, McMurray JJ. 2004 The clinical relevance of adrenomedullin: a promising profile? Pharmacology \& Therapeutics 2004;10:179-201

49. Deshmane SL, Kremlev S, Amini S, Sawaya BE. Monocyte chemoattractant protein1 (MCP-1): an overview. Journal of Interferon and Cytokine Research 2009;29:31326

50. Wojdasiewicz P, Poniatowski LA, Kotela A, Deszczynski J, Kotela I, Szukiewicz D. The chemokine CX3CL1 (fractalkine) and its receptor CX3CR1: occurrence and potential role in osteoarthritis. Archivum Immunologiae et Therapia Experimentalis 2014;62:395-403

51. Muller A, Homey B, Soto $H, G e N$, Catron D, Buchanan ME, et al. Involvement of chemokine receptors in breast cancer metastasis. Nature 2001;410:50-6

52. Asou Y, Rittling SR, Yoshitake H, Tsuji K, Shinomiya K, Nifuji A, et al. Osteopontin facilitates angiogenesis, accumulation of osteoclasts, and resorption in ectopic bone. Endocrinology 2001;142:1325-32

53. Koeneman KS, Yeung F, Chung LW. Osteomimetic properties of prostate cancer cells: a hypothesis supporting the predilection of prostate cancer metastasis and growth in the bone environment. Prostate 1999;39:246-61 
54. Fata JE, Kong YY, Li J, Sasaki T, Irie-Sasaki J, Moorehead RA., et al. The osteoclast differentiation factor osteoprotegerin-ligand is essential for mammary gland development. Cell 2000;103:41-50

55. Kovacs CS. (2005). Calcium and bone metabolism during pregnancy and lactation. Journal of Mammary Gland Biology and Neoplasia 2005;10:105-18

56. Carlinfante G, Vassilioul D, Svensson D, Wendel M, Heinegard D, Andersson D. Differential expression of osteopontin and bone sialoprotein in bone metastasis of breast and prostate carcinoma. Clinical and Experimental Metastasis 2003;20:437-44

57. Tsubochi H, Endo S, Oda Y, Dobashi Y. Carcinoid tumor of the lung with massive ossification: report of a case showing the evidence of osteomimicry and review of the literature. International Journal of Clinical and Experimental Pathology 2013;6:957-61

58. Rucci N, Teti A. Osteomimicry: how tumour cells try to deceive the bone. Frontiers in Bioscience 2010;S2:907-15

59. Nguyen DX, Bos PD, Massague J. Metastasis from dissemination to organ specific colonization. Nature Reviews Cancer 2009;9:274-84

60. Savci-Heijink CD, Halfwerk H, Hooijeri GKJ, Horlings HM, Wesseling J, van de Vijver MJ. (2015) Retrospective analysis of metastatic behaviour of breast cancer subtypes. Breast Cancer Research and Treatment 2015;150:547-57

61. Subik K, Lee JF, Baxter L, Strzepek T, Costello D, Crowley P, et al.The expression patterns of ER, PR, HER2, CK5/6, EGFR, Ki-67 and AR by immunohistochemical analysis in breast cancer cell lines. Breast Cancer (Auckl) 2010;20:35-41

62. Aapro M, Abrahamsson PA, Body JJ, Coleman RE, Colomer R, Costa L, et al. Guidance on the use of bisphosphonates in solid tumours: recommendations of an international expert pane. Annals of Oncology 2008;19:420-32 
63. National Institute for Health and Care Excellence - NICE. Advanced breast cancer (update). https://www.nice.org.uk/guidance/cg81/chapter/1-recommendations; 2009 (accessed: 25.10.14)

64. Stopeck AT, Lipton A, Body JJ, Steger GG, Tonkin K, de Boer RH, et al. Denosumab compared with zoledronic acid for the treatment of bone metastases in patients with advanced breast cancer: a randomized, double-blind study. Journal of Clinical Oncology 2010;28:5132-39

65. Wong MHF, Stockler MR, Pavlakis N. Bisphosphonates and other bone agents for breast cancer. Cochrane Database of Systematic Reviews 2012; 2:CD003474. DOI: 10.1002/14651858.CD003474.pub3

66. Ford J, Cummins E, Sharma P, Elders A, Stewart F, Johnston R, et al. Systematic review of the clinical effectiveness and cost-effectiveness, and economic evaluation, of denosumab for the treatment of bone metastases from solid tumours. Health Technology Assessment 2013;17:1+

67. Xie J, Diener M, Sorg R, Wu EQ, Namjoshi M. Cost-effectiveness of denosumab compared with zoledronic acid in patients with breast cancer and bone metastases. Clinical Breast Cancer 2012;12:247-58

68. National Institute for Health and Care Excellence - NICE. Denosumab for the prevention of skeletal-related events in adults with bone metastases from solid tumours Technology appraisal guidance. https://www.nice.org.uk/guidance/ta265?unlid=823332348201681314559; 2012 (accessed 16.9.16) 
69. Jamieson WL, Shimizu S, D'Ambrosio JA, Meucci O, Fatatis A. CX3CR1 is expressed by prostate epithelial cells and androgens regulate the levels of CX3CL1/fractalkine in bone marrow: potential role in prostate cancer bone tropism. Cancer Research 2008;68:1715-22

70. Bellahcene A, Merville MP, Castronovo V. Expression of bone sialoprotein, a bone matrix protein, in human breast cancer. Cancer Research 1996;54:2823-26

71. Bellahcene A, Antoine N, Clausse N, Tagliabue E, Fisher LW, Kerr JM, Jares P, Castronovo V. Detection of bone sialoprotein in human breast cancer tissue and cell lines at both protein and messenger ribonucleic acid levels. Laboratory Investigation $1996 ; 75: 203-10$

72. Bellacene A, Kroll M, Liebens F, Castronovo V. Bone sialoprotein expression in primary breast cancer is associated with bone metastases development. Journal of Bone Mineral Research 1996;11:665-70

73. Ibrhahim T, Leong I, Sanchez-Sweatman O, Khokha R, Sodek J, Tenenbaum HC, et al. Expression of bone sialoprotein and osteopontin in breast cancer bone metastases. Clinical \& Experimental Metastasis 2000;18:253-60

74. Bellacene A, Menard S, Bufalino R, Moreau L, Castronovo V. Expression of bone sialoprotein in primary human breast cancer is associated with poor survival. International Journal of Cancer 1996;69:350-53

75. Furger KA, Menon RK, Tuckl AB, Bramwell VH, Chambers AF. The functional and clinical roles of osteopontin in cancer and metastasis. Current Molecular Medicine $2001 ; 1: 621-32$ 
76. Weber GF. The metastasis gene osteopontin:a candidate target for cancer therapy. Biochemica et Biophysica Acta 2001;1552:61-85

77. Reinholz MM, Iturria SJ, Ingle JN, Roche PC. Differential gene expression of TGF$\beta$ family members and osteopontin in breast tumor tissue: analysis by real-time quantitative PCR. Breast Cancer Research \& Treatment 2002;74:255-69

78. Hotte SJ, Winquist EW, Stitt L, Wilson SM, Chambers AF. Plasma osteopontin: associations with survival and metastasis to bone in men with hormone-refractory prostate carcinoma. Cancer 2002;95:506-12

79. Riaz M, Sieuwerts AM, Look MP, Timmermans MA, Smid M, Foekens JA, et al. High TWIST1 mRNA expression is associated with poor prognosis in lymph node-negative and estrogen receptor-positive human breast cancer and is co-expressed with stromal as well as ECM related genes. Breast Cancer Research 2012;14:R123

80. Watson MA, Yiagan LR, Trinkhaus KM, Gillanders WE, Naughton MJ, Weilbaecher $\mathrm{KN}$, et al. Isolation and molecular profiling of bone marrow micrometastases identifies TWIST1 as a marker of early tumour relapse in breast cancer patients. Clinical Cancer Research 2007;13:5001-9

81. Zudaire E, Martinez A, Cuttita F. Adrenomedullin and cancer. Regulatory Peptides $2003 ; 112: 175-83$

82. Oehler MK, Fischer DC, Orlowska-Volk M, Herrle F, Kieback DG, Rees MC, et al. Tissue and plasma expression of the angiogenic peptide adrenomedullin in breast cancer. British Journal of Cancer 2003;89:1927-33 
83. Sotiriou C, Lacroix M, Lespagnard L, Larismont D, Paesmans M, Body JJ. Interleukins- 6 and -11 expression in primary breast cancer and subsequent development of bone metastases. Cancer Letters 2001;169:87-95

84. Geminder H, Sagi-Assif O, Goldberg L, Meshel T, Rechavi G, Witz IP, Ben-Baruch A. A possible role for CXCR4 and its ligand, the CXC chemokine stromal cell-derived factor-1, in the development of bone marrow metastases in neuroblastoma. Journal of Immunology 2001;167:4747-57

85. Taichman RS, Cooper C, Keller ET, Pienta KJ, Taichman NS, McCauley LK. Use of the stromal cell-derived factor-1 / CXCR4 pathway in prostate cancer metastasis to bone. Cancer Res 2002;62:1832-37

86. Regidor PA, Callies R, Regidor M, Schindler AE. Expression of the cell adhesion molecules ICAM-1 and VCAM-1 in the cytosol of breast cancer tissue, benign breast tissue and corresponding sera. European Journal of Gynecological Oncology 1998;19:377-83

87. Rosette C, Roth RB, Oeth P, Braun A, Kammerer S, Ekblom J, et al. Role of ICAM-1 in invasion of human breast cancer cells. Carcinogenesis 2005;26:943-50

88. Kuan CT, Wakiya K, Dowell JM, Herndon JE, Reardon DA, Graner MW, et al. Glycoprotein nonmetastatic melanoma preotein B, a potential molecular therapeutic target in patients with glioblastoma multiforme. Clinical Cancer Research $2006 ; 12: 1970-82$ 
89. Assefnia S, Dakshanamurthy S, Guidry Auvil JM, Hampel C, Anastasiadis PZ, Kallakury B, et al. Cadherin-11 in poor prognosis malignancies and rheumatoid arthritis: common target, common therapiues. Oncotarget 2013;5:1458-74

90. Valkovic T, Lucin K, Krstulja M, Dobi-Babic R, Jonic N. Expression of monocyte chemotactic protein-1 in human invasive ductal breast cancer. Pathology Research \& Practice 1998;194:335-40

91. Chavey C, Bibeau F, Gourgou-Bougade S, Burlinchon S, Boissiere F, Laune D, et al. Oestrogen receptor negative breast cancers exhibit high cytokine content. Breast Cancer Research 2007;9:R15

92. Monti P, Leone BE, Marchesi F, Balzano G, Zerbi A, Scaltrini F, et al. The CC chemokine MCP-1/CCL2 in pancreatic progression: regulation expression and potential mechanisms of antimalignant activity. Cancer Research 2003;63:7451-61

93. Vallachi V, Daniotti M, Ratti F, Di Stasi D, Deho P, De Fillipo A, et al. CCN3/nephroblastoma overexpressed matricellular protein regulates integrin expression, adhesion, and dissemination in melanoma. Cancer Research 2008;68:715-23

94. Manara MC, Perbal B, Benini S, Strammiello R, Cerisano V, Perdichizzi S, et al.The expression of ccn3(nov) gene in musculoskeletal tumors. American Journal of Pathology 2002;160:849-59

95. Maillard M, Cadot B, Ball RY, Sethia K, Edwards DR, Perbal B, et al. Differential expression of the ccn3(nov) proto-oncogene in human prostate cell lines and tissues. Molecular Pathology 2001;54:275-80 
96. Perbal B, Zuntini M, Zambelli D, Serra M, Sciandra M, Cantiani L, et al. Prognostic value of CCN3 in osteosarcoma. Clinical Cancer Research 2008;14:701-09

97. Glukhova L, Angevin E, Lavialle C, Cadot B, Terrier-Lacombe MJ, Perbal B, et al. Patterns of specific genomic alterations associated with poor prognosis in high grade renal cell carcinomas. Cancer Genetics \& Cytogenetetics 2001;130:105-10

98. Jiang WG, Watkins G, Fodstad O, Douglas-Jones A, Mokbel K, Mansel RE. Differential expression of the CCN family members Cyr61, CTGF and Nov in human breast cancer. Endocrine Related Cancer 2004;11:781-91

99. Ghayad SE, Vendrell JA, Bieche I, Spyratos F, Dumontet C, Treilleux I, et al. Identification of TACC1, NOV, and PTTG1 as new candidate genes associated with endocrine therapy resistance in breast cancer. Journal of Molecular Endocrinology $2009 ; 42: 87-103$

100. Zhang XH, Wang Q, Gerald W, Hudis CA, Norton L, Smid M, et al J. Latent bone metastasis in breast cancer tied to src-dependent survival signals. Cancer Cell 2009;16:67-78

101. Shimo T, Kubota S, Goda T, Yoshihama Y, Kurio N, Nishida T, et al. Clinical significance and pathogenic function of connective tissue growth factor (CTGF/CCN2) in osteolytic mandibular squamous cell carcinoma. Anticancer Research 2008;28:2343-48

102. Xiang ZL, Zeng ZC, Tang ZY, Fan J, He J, Zeng HY, et al. Potential biomarkers for bone metastasis from hepatocellular carcinoma. Oncologist 2011;16:1028-39 
103. Cawthorn TR, Amir E, Broom R, Freedman O, Gianfelice D, Barth D, et al Mechanisms and pathways of bone metastasis: challenges and pitfalls of performing molecular research on patient samples. Clinical \& Experimental Metastasis 2009;26:935-43

104. Casimiro S, Luis I, Fernandes A, Pires R, Pinto A, Gouveia AG, et al. Analysis of bone metastasis gene signature in patients with bone metastasis from solid tumors. Clinical \& Experimental Metastasis 2012;29:155-64 


\begin{tabular}{|c|c|c|c|c|c|}
\hline $\begin{array}{l}\text { Author and } \\
\text { publication } \\
\text { date }\end{array}$ & $\begin{array}{l}\text { Are study aims } \\
\text { clearly } \\
\text { apparent? }\end{array}$ & $\begin{array}{l}\text { Experimental } \\
\text { approaches }\end{array}$ & $\begin{array}{l}\text { What cell lines are } \\
\text { used? }\end{array}$ & $\begin{array}{l}\text { What animal } \\
\text { model is used? }\end{array}$ & Strengths and limitations of evidence presented \\
\hline $\begin{array}{l}\text { Kang et al., } \\
2003 \text { [18] }\end{array}$ & $\begin{array}{l}\text { Yes } \\
\text { To identify } \\
\text { genes that } \\
\text { mediate breast } \\
\text { cancer } \\
\text { metastases to } \\
\text { bone }\end{array}$ & $\begin{array}{l}\text { In vivo cell } \\
\text { selection and } \\
\text { gene profiling }\end{array}$ & $\begin{array}{l}\text { Bone- and adrenal- } \\
\text { metastasis specific } \\
\text { human breast } \\
\text { cancer cell clones } \\
\text { derived from } \\
\text { parental MDA-MB- } \\
231 \text { cell line }\end{array}$ & $\begin{array}{l}\text { Intracardiac } \\
\text { injection of } \\
\text { human cancer } \\
\text { cell line into } \\
\text { athymic nude } \\
\text { mice }\end{array}$ & $\begin{array}{l}\text { Rigorous selection of bone-specific human breast } \\
\text { cancer cells and demonstration of significant over } \\
\text { expression of several factors (IL-11, CTGF, CXCR4, } \\
\text { OPN) working in synergy to promote bone metastasis } \\
\text { in vivo. Functionality demonstrated by transfection of } \\
\text { genes into parental cell line. Specificity confirmed by } \\
\text { comparison of bone-specific with adrenal-specific } \\
\text { clones. MMP-1 was also highlighted as of interest in } \\
\text { this study but only preliminary data, indicated its } \\
\text { functional significance, alone or with other factors, in } \\
\text { enhancing bone metastatic ability. } \\
\text { Strong evidence for function in bone-specific } \\
\text { metastasis }\end{array}$ \\
\hline
\end{tabular}




\begin{tabular}{|c|c|c|c|c|c|}
\hline $\begin{array}{l}\text { Zhang et al., } \\
2004 \text { [19] }\end{array}$ & $\begin{array}{l}\text { Yes } \\
\text { To investigate } \\
\text { the role of bone } \\
\text { sialoprotein } \\
\text { (BSP) in breast } \\
\text { cancer } \\
\text { metastasis to } \\
\text { bone }\end{array}$ & $\begin{array}{l}\text { Cell } \\
\text { transfection } \\
\text { and in vivo } \\
\text { metastasis }\end{array}$ & $\begin{array}{l}\text { Bone- and brain- } \\
\text { seeking human } \\
\text { breast cancer cell } \\
\text { clones derived } \\
\text { from parental } \\
\text { MDA-MB-231 cell } \\
\text { line }\end{array}$ & $\begin{array}{l}\text { Intracardiac } \\
\text { injection of } \\
\text { human cancer } \\
\text { cell line into } \\
\text { athymic nude } \\
\text { mice }\end{array}$ & $\begin{array}{l}\text { Expression of BSP in a brain-seeking human breast } \\
\text { cancer cell clone resulted in } 100 \% \text { successful } \\
\text { establishment of bone metastases in vivo. } \\
\text { Strong evidence for function in bone-specific } \\
\text { metastasis }\end{array}$ \\
\hline $\begin{array}{l}\text { Rose et al., } \\
2007 \text { [20] }\end{array}$ & $\begin{array}{l}\text { Yes } \\
\text { To demonstrate } \\
\text { that osteoactivin } \\
\text { promotes bone } \\
\text { metastasis in } \\
\text { breast cancer }\end{array}$ & $\begin{array}{l}\text { In vivo } \\
\text { cancer cell } \\
\text { selection, } \\
\text { gene } \\
\text { profiling, cell } \\
\text { transfection } \\
\text { and in vivo } \\
\text { metastasis }\end{array}$ & $\begin{array}{l}\text { Bone-seeking } \\
\text { clones of mouse } \\
\text { mammary cancer } \\
\text { 4T1 }\end{array}$ & $\begin{array}{l}\text { Intracardiac } \\
\text { injection into } \\
\text { immunocompe } \\
\text { tent BALB/c } \\
\text { mice }\end{array}$ & $\begin{array}{l}\text { Consistent demonstration of osteoactivin in multiple } \\
\text { bone-seeking clones, confirmed by several } \\
\text { complimentary techniques. Expression of osteoactivin } \\
\text { by a non-bone metastasising clone imparted bone } \\
\text { metastastic ability. However, the use of murine cell } \\
\text { lines, albeit in an immunocompetent host, limits the } \\
\text { relevance of the findings to human cancer. } \\
\text { Moderate evidence for function in bone-specific } \\
\text { metastasis }\end{array}$ \\
\hline $\begin{array}{l}\text { Tamura et al., } \\
2008 \text { [21] }\end{array}$ & $\begin{array}{l}\text { Yes } \\
\text { To evaluate the } \\
\text { role of cadherin- } \\
11 \text { in homing of }\end{array}$ & $\begin{array}{l}\text { In vivo } \\
\text { selection, } \\
\text { protein } \\
\text { analysis, cell }\end{array}$ & $\begin{array}{l}\text { Parental, bone- } \\
\text { seeking and brain- } \\
\text { seeking clones of } \\
\text { human breast }\end{array}$ & $\begin{array}{l}\text { Intracardiac } \\
\text { injection of } \\
\text { human cancer } \\
\text { cell line into }\end{array}$ & $\begin{array}{l}\text { The significant expression of cadherin- } 11 \text { in bone } \\
\text { seeking cell lines, reduction in recorded bone } \\
\text { metastasis with its inactivation and failure of expected } \\
\text { lung metastases in cadherin- } 11 \text { bearing cells in an }\end{array}$ \\
\hline
\end{tabular}




\begin{tabular}{|c|c|c|c|c|c|}
\hline & $\begin{array}{l}\text { breast cancer } \\
\text { cells to bone }\end{array}$ & $\begin{array}{l}\text { transfection } \\
\text { and in vivo } \\
\text { metastasis }\end{array}$ & $\begin{array}{l}\text { cancer cell line } \\
\text { MDA-MB-231 }\end{array}$ & $\begin{array}{l}\text { athymic nude } \\
\text { mice }\end{array}$ & $\begin{array}{l}\text { animal model that usually produces lung metastases } \\
\text { all provide strong evidence for a functional role in } \\
\text { promoting breast cancer bone metastasis. } \\
\text { Strong evidence for function in bone-specific } \\
\text { metastasis }\end{array}$ \\
\hline $\begin{array}{l}\text { Takahashi et } \\
\text { al., 2008 [22] }\end{array}$ & $\begin{array}{l}\text { Yes } \\
\text { To investigate } \\
\text { the function of } \\
\text { ICAM-1 in highly } \\
\text { bone metastatic } \\
\text { breast cancer } \\
\text { cells }\end{array}$ & $\begin{array}{l}\text { In vivo } \\
\text { selection, } \\
\text { gene } \\
\text { profiling, in } \\
\text { vivo } \\
\text { metastasis, } \\
\text { in vitro } \\
\text { functional } \\
\text { testing }\end{array}$ & $\begin{array}{l}\text { Mouse mammary } \\
\text { cancer } 4 \mathrm{~T} 1 \text { and a } \\
\text { highly metastatic } \\
\text { variant } 4 \mathrm{~T} 1 \mathrm{E} / \mathrm{M} 3\end{array}$ & $\begin{array}{l}\text { Tail vein } \\
\text { injection into } \\
\text { immunocompe } \\
\text { tent BALB/c } \\
\text { mice }\end{array}$ & $\begin{array}{l}\text { ICAM-1 and beta } 2 \text { integrin expression in bone } \\
\text { seeking cells was demonstrated using multiple } \\
\text { techniques identifying their expression at both } \\
\text { genomic and transcriptomic level. Functionality of } \\
\text { ICAM-1 was explored, but not beta } 2 \text { integrin, and this } \\
\text { is a limitation of the study. In discussion, it is } \\
\text { mentioned that anti-ICAM-1 and anti-beta } 2 \text { integrin } \\
\text { antibodies had no inhibitory effect on } 4 \mathrm{~T} 1 \mathrm{E} / \mathrm{M} 3 \\
\text { adhesion to bone marrow derived endothelial cells, } \\
\text { but data is not presented. Further, } 4 \mathrm{~T} 1 \mathrm{E} / \mathrm{M} 3 \text { cells were } \\
\text { not exclusively metastatic to bone and showed a high } \\
\text { level of metastasis to lung, as well as, less commonly, } \\
\text { other sites. A further limitation of the study is the use } \\
\text { of murine cells, albeit in an immunocompetent host. } \\
\text { Moderate evidence for ICAM-1function in bone- } \\
\text { specific metastasis }\end{array}$ \\
\hline
\end{tabular}




\begin{tabular}{|c|c|c|c|c|c|}
\hline $\begin{array}{l}\text { Takahashi et } \\
\text { al., 2009 [23] }\end{array}$ & $\begin{array}{l}\text { Yes } \\
\text { To examine the } \\
\text { impact of CCL2 } \\
\text { in regulating } \\
\text { breast cancer } \\
\text { bone metastasis }\end{array}$ & $\begin{array}{l}\text { In vivo cell } \\
\text { selection, } \\
\text { gene } \\
\text { profiling, in } \\
\text { vivo } \\
\text { metastasis, } \\
\text { in vitro } \\
\text { functional } \\
\text { testing }\end{array}$ & $\begin{array}{l}\text { Highly metastatic } \\
\text { variant } 4 \mathrm{~T} 1 \mathrm{E} / \mathrm{M} 3 \text { of } \\
\text { mouse mammary } \\
\text { cancer } 4 \mathrm{~T} 1\end{array}$ & $\begin{array}{l}\text { Intravenous } \\
\text { and } \\
\text { subcutaneous } \\
\text { injection into } \\
\text { immunocompe } \\
\text { tetent BALB/c } \\
\text { mice }\end{array}$ & $\begin{array}{l}\text { While bone metastasis reduced with CCL2 expression } \\
\text { in a bone specific clone, there was still bone } \\
\text { metastasis in } 36 \% \text { of cases compared to } 0 \% \text { of the } \\
\text { non-bone seeking parental cells, despite expressing } \\
\text { CCL2 at similar levels. Moreover, a further limitation } \\
\text { of the study is the use of murine cells, albeit in an } \\
\text { immunocompetent host. } \\
\text { Weak evidence for function in bone specific } \\
\text { metastasis. }\end{array}$ \\
\hline $\begin{array}{l}\text { Lau et al., } \\
2010 \text { [24] }\end{array}$ & $\begin{array}{l}\text { Yes } \\
\text { To evaluate the } \\
\text { role of CITED2 } \\
\text { in promoting } \\
\text { osteotropism in } \\
\text { breast cancer }\end{array}$ & $\begin{array}{l}\text { In vivo } \\
\text { selection, } \\
\text { gene } \\
\text { profiling, } \\
\text { gene } \\
\text { knockdown } \\
\text { and in vivo } \\
\text { metastasis }\end{array}$ & $\begin{array}{l}\text { neu-expressing } \\
\text { mammary tumor } \\
\text { cell line NT2.5 and } \\
\text { subclones with } \\
\text { differing metastatic } \\
\text { capability } \\
\text { Human bone } \\
\text { metastatic MDA- } \\
\text { MB-231 and MDA- } \\
\text { MB-468, and non- } \\
\text { metastatic } 11-24 \\
\text { HME and MCF- }\end{array}$ & $\begin{array}{l}\text { Intracardiac } \\
\text { injection of } \\
\text { murine and } \\
\text { human cancer } \\
\text { cells into neu- } \\
\mathrm{N} \text { mice }\end{array}$ & $\begin{array}{l}\text { CITED2 expression was clearly correlated with } \\
\text { increased bone metastatic potential in both murine } \\
\text { and human cell lines using several different } \\
\text { techniques. } \\
\text { Strong evidence for function in bone specific } \\
\text { metastasis. }\end{array}$ \\
\hline
\end{tabular}




\begin{tabular}{|c|c|c|c|c|c|}
\hline & & & $10 \mathrm{~A}$ & & \\
\hline $\begin{array}{l}\text { Ouellet et al., } \\
2011 \text { [25] }\end{array}$ & $\begin{array}{l}\text { Yes } \\
\text { To evaluate the } \\
\text { role of CCN3 in } \\
\text { breast cancer } \\
\text { metastasis to } \\
\text { bone }\end{array}$ & $\begin{array}{l}\text { In vivo } \\
\text { selection, } \\
\text { protein } \\
\text { analysis, cell } \\
\text { transfection } \\
\text { and in vivo } \\
\text { metastasis, } \\
\text { in vitro } \\
\text { functional } \\
\text { testing }\end{array}$ & $\begin{array}{l}\text { Mouse mammary } \\
\text { cancer } 4 \mathrm{~T} 1 \\
\text { Weakly bone } \\
\text { metastatic mouse } \\
\text { mammary cancer } \\
\text { cell line } 66 \mathrm{cl} 4\end{array}$ & $\begin{array}{l}\text { Intracardiac } \\
\text { injection into } \\
\text { immunocompe } \\
\text { tent BALB/c } \\
\text { mice }\end{array}$ & $\begin{array}{l}\text { Functionality of CCN3 was demonstrated by showing } \\
\text { that CCN3 expression increased bone metastatic } \\
\text { tendency in a cell line that is naturally poorly } \\
\text { metastatic. However, in addition to the use of murine } \\
\text { cell lines, albeit in immunocompetent animals, no } \\
\text { report of sites of metastasis other than bone were } \\
\text { mentioned, making it impossible to assess the bone } \\
\text { specificity for the effect of this factor } \\
\text { Weak evidence for function in bone specific } \\
\text { metastasis. }\end{array}$ \\
\hline $\begin{array}{l}\text { Jamieson- } \\
\text { Gladney et al., } \\
2011[26]\end{array}$ & $\begin{array}{l}\text { Yes } \\
\text { To investigate } \\
\text { the role of } \\
\text { fractalkine and } \\
\text { its receptor } \\
\mathrm{CX}_{3} \mathrm{CR} 1 \text { in bone } \\
\text { metastasis from } \\
\text { breast cancer }\end{array}$ & $\begin{array}{l}\text { Cell } \\
\text { transfection } \\
\text { and in vivo } \\
\text { metastasis }\end{array}$ & $\begin{array}{l}\text { Human breast } \\
\text { cancer cell lines } \\
\text { MDA-MB-231, } \\
\text { MDA-MB-436 }\end{array}$ & $\begin{array}{l}\text { Intracardiac } \\
\text { injection into } \\
\text { SCID mice or } \\
\text { control non- } \\
\text { immune } \\
\text { compromised } \\
\text { mice; } \\
\text { fractakine null } \\
\text { transgenic } \\
\text { mice }\end{array}$ & $\begin{array}{l}\text { Functional role of } \mathrm{CX}_{3} \mathrm{CR} 1 \text { is demonstrated by } \\
\text { knockdown experiments. Bone specificity is } \\
\text { demonstrated by comparison with adrenal } \\
\text { metastases. Some evidence of bone metastasis was } \\
\text { seen in mice null for } \mathrm{CX}_{3} \mathrm{CR} 1 \text { binding partner, } \\
\text { fractalkine, suggesting that other factors, not } \\
\text { considered in the study, may be implicated } \\
\text { Moderate evidence for function in bone specific } \\
\text { metastasis. }\end{array}$ \\
\hline
\end{tabular}




\begin{tabular}{|c|c|c|c|c|c|}
\hline $\begin{array}{l}\text { Lau et al., } \\
2013 \text { [27] }\end{array}$ & $\begin{array}{l}\text { Yes } \\
\text { To evaluate the } \\
\text { role of Enpp1 in } \\
\text { breast cancer } \\
\text { bone metastasis }\end{array}$ & $\begin{array}{l}\text { In vivo } \\
\text { selection, } \\
\text { gene } \\
\text { profiling, } \\
\text { protein } \\
\text { analysis, cell } \\
\text { transfection } \\
\text { and in vivo } \\
\text { metastasis }\end{array}$ & $\begin{array}{l}\text { HER-2/neu- } \\
\text { expressing mouse } \\
\text { mammary tumour } \\
\text { cell line, NT2.5 } \\
\text { Human breast } \\
\text { cancer cell lines } \\
\text { MDA-MB-231, } \\
\text { MDA-MB-468 }\end{array}$ & $\begin{array}{l}\text { intracardiac } \\
\text { and intra-tibial } \\
\text { injection into } \\
\text { athymic nude } \\
\text { mice }\end{array}$ & $\begin{array}{l}\text { While the authors state that Enpp1 was identified in } \\
\text { their previous study Lau et al (2009) as being of } \\
\text { special interest, it does not actually appear as a gene } \\
\text { of interest in that paper. } \\
\text { Enpp1 expression was increased in bone seeking } \\
\text { murine and human breast cancer cells and in human } \\
\text { breast cancer bone metastases in comparison to } \\
\text { primary tumours and normal breast epithelium. } \\
\text { Expression of Enpp1 by MDA-MB-231 cells resulted in } \\
\text { no greater rate of bone metastasis, but more rapid } \\
\text { bone destruction. } \\
\text { Moderate evidence for function in bone specific } \\
\text { metastasis. }\end{array}$ \\
\hline $\begin{array}{l}\text { Croset et al., } \\
2014 \text { [28] }\end{array}$ & $\begin{array}{l}\text { Yes } \\
\text { To explore the } \\
\text { functions of } \\
\text { TWIST1 in } \\
\text { breast cancer } \\
\text { bone metastasis }\end{array}$ & $\begin{array}{l}\text { Cell } \\
\text { transfection, } \\
\text { in vivo } \\
\text { inoculation, } \\
\text { in vitro } \\
\text { functional } \\
\text { testing }\end{array}$ & $\begin{array}{l}\text { MDA-MB-231/BO2, } \\
\text { a bone metastatic } \\
\text { clone of human } \\
\text { breast cancer cell } \\
\text { line. } \\
\text { Human MCF-7 and } \\
\text { mouse } 4 \mathrm{~T} 1 \text { breast }\end{array}$ & $\begin{array}{l}\text { Tail artery } \\
\text { injection into } \\
\text { nude mice. } \\
\text { Assessment of } \\
\text { primary tumour } \\
\text { growth was } \\
\text { achieved by }\end{array}$ & $\begin{array}{l}\text { MDA-MB-231/BO2 cells demonstrated earlier and } \\
\text { significantly larger osteolytic bone metastasis } \\
\text { compared to control when TWIST1 was exogenously } \\
\text { expressed in them. TWIST1 was, however, not found } \\
\text { to be inherently expressed in MDA-MB-231/BO2 and } \\
\text { other bone metastatic clones. } \\
\text { Weak evidence for function in bone specific }\end{array}$ \\
\hline
\end{tabular}




\begin{tabular}{|c|c|c|c|c|c|}
\hline & & & cancer cell lines & $\begin{array}{l}\text { xenograft into } \\
\text { the mammary } \\
\text { fat pad. }\end{array}$ & metastasis. \\
\hline $\begin{array}{l}\text { Siclari et al., } \\
2014 \text { [29] }\end{array}$ & $\begin{array}{l}\text { Yes } \\
\text { To evaluate the } \\
\text { role of } \\
\text { adrenomedullin } \\
\text { in enhancing } \\
\text { bone metastasis } \\
\text { in breast cancer } \\
\text { and explore its } \\
\text { potential as a } \\
\text { therapeutic } \\
\text { target for } \\
\text { treatment of } \\
\text { bone metastasis }\end{array}$ & $\begin{array}{l}\text { cell } \\
\text { transfection } \\
\text { and in vivo } \\
\text { metastasis, } \\
\text { ex vivo co- } \\
\text { culture and } \\
\text { functional } \\
\text { analysis }\end{array}$ & $\begin{array}{l}\text { Multiple breast } \\
\text { cancer cell lines } \\
\text { were tested for } \\
\text { adrenomedullin } \\
\text { expression. } \\
\text { MDA-MB-231 } \\
\text { clones were used } \\
\text { for gene } \\
\text { transfection and } \\
\text { mice inoculation }\end{array}$ & $\begin{array}{l}\text { Intracardiac } \\
\text { injection into } \\
\text { athymic nude } \\
\text { mice }\end{array}$ & $\begin{array}{l}\text { Clear demonstration of a functional role for } \\
\text { adrenomedullin in enhancing osteolytic metastasis. } \\
\text { Adrenomedullin was found to be expressed in normal } \\
\text { tissues (including breast, kidney and prostate) and } \\
\text { lung metastases, suggesting that adrenomedullin may } \\
\text { not only contribute to specific bone tropism. } \\
\text { Adrenomedullin is more likely contribute to growth of } \\
\text { already formed bone metastasesrather than playing a } \\
\text { causal role. } \\
\text { Moderate evidence for function in bone specific } \\
\text { metastasis. }\end{array}$ \\
\hline
\end{tabular}




\begin{tabular}{|c|c|c|c|c|c|}
\hline $\begin{array}{l}\text { Author and } \\
\text { publication } \\
\text { date }\end{array}$ & $\begin{array}{l}\text { Functional factor(s) } \\
\text { identified }\end{array}$ & $\begin{array}{l}\text { Wild type function } \\
\text { of } \\
\text { molecular } \\
\text { factor(s) }\end{array}$ & $\begin{array}{l}\text { Functional } \\
\text { classification of } \\
\text { molecular } \\
\text { factor(s) }\end{array}$ & Summary of main study findings & $\begin{array}{l}\text { Brief interpretation of study } \\
\text { findings }\end{array}$ \\
\hline $\begin{array}{l}\text { Kang et al., } \\
2003[18]\end{array}$ & $\begin{array}{l}\text { IL } 11 \\
\text { Connective tissue } \\
\text { growth factor CTGF } \\
\text { (CCN2) } \\
\text { CXCR4 }\end{array}$ & $\begin{array}{l}\text { osteoclast } \\
\text { formation; further } \\
\text { activated by } \\
\text { TGFbeta } \\
\text { Osteoblast } \\
\text { differentiation } \\
\text { and proliferation, } \\
\text { angiogenesis; } \\
\text { further activated } \\
\text { by TGFbeta } \\
\text { a chemokine } \\
\text { receptor involved } \\
\text { in chemotaxis, } \\
\text { cell proliferation }\end{array}$ & $\begin{array}{l}\text { Cytokine / } \\
\text { growth factor } \\
\text { Cytokine / } \\
\text { growth factor } \\
\\
\text { Chemokine } \\
\text { receptor }\end{array}$ & $\begin{array}{l}\text { In vivo selection of bone- and adrenal-metastasis } \\
\text { specific human breast cancer cell clones derived } \\
\text { from MDA-MB-231 and determination of bone- } \\
\text { specific, and not adrenal-specific, metastasis gene } \\
\text { signature. } \\
\text { Confirmation that parental and bone-metastatic } \\
\text { subclones conform to a previously established poor } \\
\text { prognosis gene signature, and no evidence that } \\
\text { acquisition of bone-homing activity is associated with } \\
\text { increased expression of these genes. Further } \\
\text { analysis revealed distinct gene signatures } \\
\text { associated with clones that selectively metastasise } \\
\text { to bone and to adrenal gland, and bone-metastasis- } \\
\text { associated genes distinct from the previously } \\
\text { established poor prognosis gene signature. IL11, }\end{array}$ & $\begin{array}{l}\text { Investigations reveal a gene } \\
\text { profile, already present in the } \\
\text { parental cell population, which, } \\
\text { when superimposed on an } \\
\text { already metastasis-associated } \\
\text { gene signature, specifically } \\
\text { enhances metastasis to bone. } \\
\text { IL11, CTGF, CXCR4 and OPN } \\
\text { are convincingly shown to work } \\
\text { synergistically. These genes } \\
\text { encode proteins associated } \\
\text { with angiogenesis, tumour cell } \\
\text { invasion, recruitment of } \\
\text { osteoclasts suggesting that } \\
\text { their action contributes to a } \\
\text { microenvironment favouring }\end{array}$ \\
\hline
\end{tabular}




\begin{tabular}{|c|c|c|c|c|c|}
\hline & $\begin{array}{l}\text { Osteopontin (OPN) } \\
\text { (early T lymphocyte } \\
\text { activation gene } 1 \\
\text { eta1, secreted } \\
\text { phosphoprotein } 1 \\
\text { spp1, bone } \\
\text { sialoprotein 1) }\end{array}$ & $\begin{array}{l}\text { Multiple } \\
\text { functions. } \\
\text { Stimulates } \\
\text { osteoclast } \\
\text { adhesion to bone } \\
\text { matrix. } \\
\text { Lymphokine. }\end{array}$ & $\begin{array}{l}\text { Extracellular } \\
\text { matrix protein / } \\
\text { cytokine }\end{array}$ & $\begin{array}{l}\text { CTGF, CXCR4 and MMP-1 were identified as the } \\
\text { most highly overexpressed in the bone-metastasis } \\
\text { populations. } \\
\text { Parental MDA-MB-231 cells transfected to express } \\
\text { high levels of IL11 required co-expression of } \\
\text { osteopontin (OPN) before enhanced bone } \\
\text { metastasis was observed. CXCR4 when expressed } \\
\text { alone resulted in limited enhanced bone metastatic } \\
\text { ability. Increased expression of CTGF alone did not. } \\
\text { Triple transfectants expressing OPN and IL11 with } \\
\text { either CXCR4 or CTGF showed dramatic enhanced } \\
\text { bone metastatic ability. Preliminary data only, not } \\
\text { shown, was suggestive of MMP-1 alone or in } \\
\text { combination with IL-11 and OPN enhancing bone } \\
\text { metastasis. } \\
\text { Populations of cells which over expressed the IL11, } \\
\text { CTGF, CXCR4, MMP1, OPN bone metastasis gene } \\
\text { signature were both found to be present in the } \\
\text { original parental MDA-MB-231population and to } \\
\text { exhibit enhanced ability to metastasise to bone. } \\
\text { Cells expressing this multi-gene signature were }\end{array}$ & $\begin{array}{l}\text { establishment of metastases. } \\
\text { Cell populations highly } \\
\text { metastatic to adrenal medulla } \\
\text { do not share this signature, } \\
\text { suggesting a basis for tissue } \\
\text { specificity. }\end{array}$ \\
\hline
\end{tabular}




\begin{tabular}{|c|c|c|c|c|c|}
\hline & & & & $\begin{array}{l}\text { found to be enriched in the bone-metastasis selected } \\
\text { clones derived from MDA-MB-231 }\end{array}$ & \\
\hline $\begin{array}{l}\text { Zhang et al., } \\
2004[19]\end{array}$ & $\begin{array}{l}\text { Bone sialoprotein } \\
\text { (BSP, bone } \\
\text { sialoprotein II) }\end{array}$ & $\begin{array}{l}\text { Bone } \\
\text { homeostasis }\end{array}$ & $\begin{array}{l}\text { Extracellular } \\
\text { matrix protein }\end{array}$ & $\begin{array}{l}\text { Exclusively bone- and brain-seeking clones derived } \\
\text { from MDA-231 cells were established. Upon } \\
\text { transfection with BSP, the brain-seeking clones } \\
\text { formed bone metastases. Transfection with vector } \\
\text { only had no effect. Bone lesions, detected by } \\
\text { radiological examination, were also examined using } \\
\text { standard histological techniques, and in situ } \\
\text { hybridisation and immunohistochemistry to localise } \\
\text { BSP. High levels of BSP mRNA and protein were } \\
\text { localised in the bone metastases. }\end{array}$ & $\begin{array}{l}\text { Convincing evidence for the } \\
\text { role of BSP in establishment of } \\
\text { bone metastasis was shown in } \\
\text { this study as its expression } \\
\text { caused significant bone } \\
\text { metastasis in a completely } \\
\text { non-bone seeking cell line }\end{array}$ \\
\hline $\begin{array}{l}\text { Rose et al., } \\
2007 \text { [20] }\end{array}$ & Osteoactivin & $\begin{array}{l}\text { Involved in } \\
\text { osteoblast } \\
\text { differentiation } \\
\text { and osteoclast } \\
\text { formation }\end{array}$ & $\begin{array}{l}\text { Cell adhesion } \\
\text { protein }\end{array}$ & $\begin{array}{l}\text { Sub-populations of } 4 \mathrm{~T} 1 \text { cancer cells showing } \\
\text { enhanced metastasis to bone were selected. These } \\
\text { cells were more motile and more invasive than the } \\
\text { parental cell line or cells selected to be tumorigenic } \\
\text { and non-metastatic, or metastatic to lung but not } \\
\text { bone. } \\
\text { Gene expression profiling using microarray identified } \\
\text { a range of } 12 \text { genes with elevated expression and } 4 \\
\text { with lower expression in strongly bone-metastasising }\end{array}$ & $\begin{array}{l}\text { Compelling evidence is } \\
\text { presented that osteoactivin } \\
\text { expression is necessary and } \\
\text { sufficient for MMP-3 } \\
\text { expression and also } \\
\text { associated with enhanced } \\
\text { invasiveness, probably in } \\
\text { conjunction with other } \\
\text { mediators, in selected bone- } \\
\text { seeking cell populations. }\end{array}$ \\
\hline
\end{tabular}




\begin{tabular}{|c|c|c|c|c|c|}
\hline $\begin{array}{l}\text { Tamura et al., } \\
2008 \text { [21] }\end{array}$ & $\begin{array}{l}\text { Cadherin-11 } \\
(\mathrm{CDH} 11)\end{array}$ & $\begin{array}{l}\text { Cell adhesion } \\
\text { molecule, } \\
\text { mediates cell } \\
\text { adhesion through } \\
\text { homophilic } \\
\text { interactions. } \\
\text { Expressed by } \\
\text { bone marrow } \\
\text { cells and } \\
\text { osteoblasts. }\end{array}$ & $\begin{array}{l}\text { Cell adhesion } \\
\text { protein }\end{array}$ & $\begin{array}{l}\text { Cadherin-11 expression was markedly increased in } \\
\text { bone-seeking clones of MDA-MB- } 231 \text { cells in } \\
\text { comparison to the parental cell line or to brain- } \\
\text { seeking clones. } \\
\text { MDA-MB-231 cells stably transfected with intact } \\
\text { cadeherin-11 and an inactive variant that is unable } \\
\text { to form homophilic interactions. The cells expressing } \\
\text { intact cadherin-11 showed increased bone } \\
\text { metastases in an animal model compared to the } \\
\text { parental cell line. Cells expressing inactive } \\
\text { cadherin-11 showed reduced bone metastasis. No } \\
\text { difference in ability to metastasise to lung was noted, } \\
\text { thus indicating that cadherin-11 is specifically } \\
\text { involved in establishment of bone metastases. } \\
\text { These observations were supported by evidence } \\
\text { that cadherin-11- positive cancer cells arrested in } \\
\text { greater numbers in bone marrow than cells of the } \\
\text { parental line, and that cells expressing inactive } \\
\text { cadherin-11 arrested in decreased numbers. When } \\
\text { co-cultured with a cadherin-11 expressing bone } \\
\text { stromal cell line, increased migration of the cancer } \\
\text { cells was observed, and this was not seen in co- }\end{array}$ & $\begin{array}{l}\text { Increased e expression of } \\
\text { cadherin-11 in bone-seeking } \\
\text { cell clones, increased bone } \\
\text { metastasis when cadherin-11 } \\
\text { is expressed and reduction in } \\
\text { bone metastasis when an } \\
\text { inactive variant is expressed all } \\
\text { provide evidence for cadherin- } \\
11 \text { promoting metastasis to } \\
\text { bone. Evidence is provided } \\
\text { that this is an organ-specific } \\
\text { phenomenon as no } \\
\text { relationship between cadherin- } \\
11 \text { and increased metastasis to } \\
\text { other sites (brain, lung) is } \\
\text { observed. Furthermore, } \\
\text { evidence is provided that the } \\
\text { mechanism of action is through } \\
\text { homophilic cell-cell adhesive } \\
\text { interactions between cadherin- } \\
11 \text { positive cancer cells and } \\
\text { cadherin- } 11 \text { positive bone } \\
\text { stromal cells resulting in }\end{array}$ \\
\hline
\end{tabular}




\begin{tabular}{|c|c|c|c|c|c|}
\hline & & & & $\begin{array}{l}\text { culture experiments using a non-cadherin-11 } \\
\text { expressing fibroblast cell line. } \\
\text { Immunohistochemistry revealed that cadherin-11- } \\
\text { positive cancer cells formed homophilic cell-cell } \\
\text { interactions with bone stromal cells. Moreover, in a } \\
\text { co-culture system, homophilic interactions between } \\
\text { cadherin-11 on cancer cells and on mouse } \\
\text { osteoblastic cells resulted in up-regulation of the } \\
\text { osteoclastogenic cytokine PTH-rP by the cancer } \\
\text { cells. }\end{array}$ & $\begin{array}{l}\text { increased cancer cell migration } \\
\text { and up-regulation of the } \\
\text { osteoclastogenic cytokine } \\
\text { PTH-rP by the cancer cells. } \\
\text { Thus, cadherin-11 expression } \\
\text { by breast cancer cells } \\
\text { promotes, through homophilic } \\
\text { interaction with cadherin-11 } \\
\text { expressed on bone stromal } \\
\text { cells, cancer cell homing } \\
\text { specifically to bone, then } \\
\text { directed migration and } \\
\text { osteoclastogenesis }\end{array}$ \\
\hline $\begin{array}{l}\text { Takahashi et } \\
\text { al., } 2008 \text { [22] }\end{array}$ & ICAM-1 & $\begin{array}{l}\text { Cell adhesion } \\
\text { molecule and } \\
\text { member of the } \\
\text { immunoglobulin } \\
\text { superfamily. } \\
\text { Mediates cell to } \\
\text { cell interaction of } \\
\text { osteoblast and } \\
\text { osteoclast } \\
\text { precursor cells in }\end{array}$ & $\begin{array}{l}\text { Cell adhesion } \\
\text { protein }\end{array}$ & $\begin{array}{l}\text { Rigorous in vivo selection of } 4 \mathrm{~T} 1 \mathrm{E} \text { cells was } \\
\text { performed to develop a cell line with enhanced } \\
\text { metastasis, } 4 \mathrm{~T} 1 \mathrm{E} / \mathrm{M} 3 \text {. The cells, which were highly } \\
\text { clonal, showed enhanced bone metastasis but } \\
\text { metastasised to other sites, including liver, spleen, } \\
\text { heart, and, especially lung. Cells of } 4 \mathrm{~T} 1 \mathrm{E} / \mathrm{M} 3 \\
\text { proliferated only slightly faster than the parental line, } \\
\text { but exhibited increased adhesion to both plasticware } \\
\text { and to bone marrow derived endothelial cells, were } \\
\text { more motile in a wound healing assay and showed }\end{array}$ & $\begin{array}{l}\text { Increased ICAM-1 and beta } 2 \\
\text { integrin expression in bone } \\
\text { seeking cells was } \\
\text { demonstrated. Further, } \\
\text { functional significance of } \\
\text { ICAM-1 was demonstrated by } \\
\text { the inhibitory action of anti- } \\
\text { ICAM-1 antibody on migration } \\
\text { and colony formation. }\end{array}$ \\
\hline
\end{tabular}




\begin{tabular}{|c|c|c|c|c|c|}
\hline & & $\begin{array}{l}\text { osteoclast } \\
\text { formation, } \\
\text { leukocyte } \\
\text { migration in } \\
\text { inflammation }\end{array}$ & & $\begin{array}{l}\text { increased anchorage independent proliferation in } \\
\text { soft agar. They express increased levels of ICAM-1 } \\
\text { and beta } 2 \text { integrin and anti-ICAM-1 antibodies } \\
\text { inhibit their migration and colony formation. }\end{array}$ & \\
\hline $\begin{array}{l}\text { Takahashi et } \\
\text { al., } 2009 \text { [23] }\end{array}$ & $\begin{array}{l}\text { CCL2 (chemokine } \\
\text { C-C ligand 2, } \\
\text { monocyte } \\
\text { chemoattractant } \\
\text { protein-1, MCP-1) }\end{array}$ & $\begin{array}{l}\text { Member of the } \\
\text { CC chemokine } \\
\text { superfamily. } \\
\text { Involved in } \\
\text { mediating } \\
\text { leukocyte } \\
\text { migration }\end{array}$ & $\begin{array}{l}\text { Cytokine / } \\
\text { growth factor }\end{array}$ & $\begin{array}{l}\text { Further exploration of the enhanced bone and lung } \\
\text { metastatic 4T1E/M3 cells established previously by } \\
\text { this group reveal that CCL2 is much reduced in } \\
\text { comparison to the parental cell line. Its restitution } \\
\text { diminishes the cells metastatic ability to colonise } \\
\text { bone and lung, reduces their migration and } \\
\text { anchorage independent growth and downregulates } \\
\text { expression of ICAM-1. Conversely, knocking down } \\
\text { CCL2 in the parental cell line renders it more } \\
\text { metastatic and this is associated with increased } \\
\text { expression of ICAM-1. Knockdown of ICAM-1 in } \\
4 T 1 E / M 3 \text { cells does not increase CCL2 production, } \\
\text { but knocking down CCL2 does result in upregulation } \\
\text { of ICAM-1, suggesting that CCL2 is an upstream } \\
\text { modulator of ICAM-1 expression. }\end{array}$ & $\begin{array}{l}\text { In this study, a continuation of } \\
\text { Takahashi et al (2008), the } \\
\text { authors further explore } \\
\text { molecular players responsible } \\
\text { for enhanced metastatic ability } \\
\text { of } 4 \text { T1E/M3 cells in } \\
\text { comparison to the parental } \\
\text { cell line. Here, down } \\
\text { regulation of CCL2 is shown } \\
\text { to be associated with } \\
\text { enhanced metastasis to both } \\
\text { lung and bone, and an } \\
\text { interesting interaction between } \\
\text { CCL2 and ICAM-1, identified } \\
\text { in the previous study as being } \\
\text { positively associated with } \\
\text { enhanced metastasis, is } \\
\text { demonstrated. Further }\end{array}$ \\
\hline
\end{tabular}




\begin{tabular}{|c|c|c|c|c|c|}
\hline & & & & & $\begin{array}{l}\text { evidence is presented that } \\
\text { CCL2 is an upstream } \\
\text { modulator of ICAM-1 } \\
\text { expression. }\end{array}$ \\
\hline $\begin{array}{l}\text { Lau et al., } \\
2010 \text { [24] }\end{array}$ & CITED2 & $\begin{array}{l}\text { A transcriptional } \\
\text { co-activator } \\
\text { involves } \\
\text { regulation of } \\
\text { haematopoiesis }\end{array}$ & $\begin{array}{l}\text { Intracellular } \\
\text { signalling protein }\end{array}$ & $\begin{array}{l}\text { Expression of a number of genes, including CCL9, } \\
\text { Ephrin B2, CTGF, and CITED2 was significantly } \\
\text { over-expressed in highly bone metastatic murine cell } \\
\text { line (BO6) compared to the poorly bone metastatic } \\
\text { clones and parent cell line (LI and NT2.5 } \\
\text { respectively) using microarray analysis. CITED2 was } \\
\text { chosen for further analysis. CITED2 expression was } \\
\text { significantly increased in bone metastatic human } \\
\text { breast cancer cell lines (MDA-MB-231 and MDA-MB- } \\
468 \text { ) compared to non-metastatic ones ( } 11-24 \text { HME } \\
\text { and MCF-10A) using quantitative PCR analysis and } \\
\text { levels were elevated in human primary invasive } \\
\text { breast cancer samples in comparison with normal } \\
\text { breast epithelium, and elevated in clinical bone } \\
\text { metastases. } \\
\text { Silencing of CITED2 expression by NT2.5 cells did } \\
\text { not cause any change in rate of cell proliferation, but } \\
\text { resulted in reduced bone metastasis. }\end{array}$ & $\begin{array}{l}\text { Strong evidence was shown } \\
\text { for CITED2 as expression was } \\
\text { clearly correlated with } \\
\text { increased bone metastatic } \\
\text { potential in both murine and } \\
\text { human breast cancer cell lines } \\
\text { using complementary } \\
\text { approaches. } \\
\text { Immunocompetent mice were } \\
\text { used for animal inoculation } \\
\text { bearing more similitude to } \\
\text { natural tumour environment. }\end{array}$ \\
\hline
\end{tabular}




\begin{tabular}{|c|c|c|c|c|c|}
\hline $\begin{array}{l}\text { Ouellet et al., } \\
2011 \text { [25] }\end{array}$ & $\begin{array}{l}\mathrm{CCN3} \\
\text { (NOV) }\end{array}$ & $\begin{array}{l}\text { Matricellular } \\
\text { protein that } \\
\text { regulates } \\
\text { osteoblast } \\
\text { differentiation, } \\
\text { function in cell } \\
\text { adhesion }\end{array}$ & $\begin{array}{l}\text { Extracellular } \\
\text { matrix protein }\end{array}$ & $\begin{array}{l}\text { This study continues from the work of Rose et al } \\
\text { (2007) in which sub-populations of } 4 \mathrm{~T} 1 \text { cancer cells } \\
\text { showing enhanced metastasis to bone were } \\
\text { selected. Further analysis, reported here, } \\
\text { demonstrated over-expression of CCN3 in these } \\
\text { cells in comparison to weakly bone metastatic } \\
\text { counterparts. A variety of complementary techniques } \\
\text { were employed, including microarray analysis, } \\
\text { quantitative PCR, immunoblotting and } \\
\text { immunofluorescence. } \\
\text { Immunohistochemical staining for CCN3 in human } \\
\text { breast cancer bone metastasis samples revealed } \\
\text { that that most (11 out of } 14 \text { ) stained moderately to } \\
\text { strongly for CCN3 and that CCN3 was also abundant } \\
\text { in the bone stroma. } \\
\text { Weakly bone metastatic murine breast cancer cell } \\
\text { line } 66 \text { cl } 4 \text { showed doubled tendency to form bone } \\
\text { metastasis on transfection with CCN3 cDNA. } \\
\text { In vitro, CCN3 was shown to inhibit osteoclast } \\
\text { differentiation and result in an increased }\end{array}$ & $\begin{array}{l}\text { Functionality of CCN3 was } \\
\text { demonstrated by showing that } \\
\text { CCN3 transfection increased } \\
\text { bone metastatic tendency in a } \\
\text { cell line that is naturally poorly } \\
\text { bone metastatic. However, no } \\
\text { report of other sites of } \\
\text { metastasis was given to } \\
\text { assess bone specificity of } \\
\text { CCN3.That CCN3 is of } \\
\text { importance in formation of } \\
\text { bone metastasis is, however, } \\
\text { much strengthened by the } \\
\text { careful and complimentary } \\
\text { experiments seeking to } \\
\text { determine functional effects in } \\
\text { influencing osteoclast } \\
\text { formation. }\end{array}$ \\
\hline
\end{tabular}




\begin{tabular}{|c|c|c|c|c|c|}
\hline & & & & $\begin{array}{l}\text { RANKL/OPG ratio. Furthermore, CCN3 could induce } \\
\text { osteclastogenesis in rRANKL primed cells through } \\
\text { immobilising Ca2+ ions and induced nfact 1nuclear } \\
\text { localisation, which is important in octeoclast } \\
\text { differentiation. Evidence is also presented that CCN3 } \\
\text { induced osteoclast differentiation involves JNK and } \\
\text { PKC signalling }\end{array}$ & \\
\hline $\begin{array}{l}\text { Jamieson- } \\
\text { Gladney et al., } \\
2011[26]\end{array}$ & $\mathrm{CX}_{3} \mathrm{CR} 1$ & $\begin{array}{l}\text { Chemokine } \\
\text { receptor. Binds to } \\
\text { CX3CL1or } \\
\text { fractalkine (FKN). } \\
\text { Mediates } \\
\text { leukocyte } \\
\text { migration and } \\
\text { adhesion during } \\
\text { immune } \\
\text { response }\end{array}$ & $\begin{array}{l}\text { Chemokine } \\
\text { receptor and } \\
\text { adhesion } \\
\text { molecule }\end{array}$ & $\begin{array}{l}\text { Both normal and malignant human breast biopsies } \\
\text { were shown to express } \mathrm{CX}_{3} \mathrm{CR} 1 \text { by } \\
\text { immunohistochemistry of tissue microarrays. } \\
\text { Expression and distribution increased with malignant } \\
\text { transformation. } \\
\text { Using Western blotting, bone metastatic human } \\
\text { breast cancer cell line MDA-MB-231 was shown to } \\
\text { express high levels of } \mathrm{CX}_{3} \mathrm{CR} 1 \text { while MDA-MB-436 } \\
\text { did not. The CX }{ }_{3} \mathrm{CR} 1 \text { positive cells showed a greater } \\
\text { propensity to establish bone metastases in an } \\
\text { animal model than the CX }{ }_{3} \mathrm{CR} 1 \text { negative cells. } \\
\text { FKN-null mice were inoculated with } \mathrm{CX}_{3} \mathrm{CR} 11 \\
\text { expressing MDA-MB-231 cell and over } 70 \% \\
\text { reduction in the disseminated tumour cells homing to }\end{array}$ & $\begin{array}{l}\text { Highly convincing evidence } \\
\text { that } \mathrm{CX}_{3} \mathrm{CR} 1 \text { expressed on } \\
\text { blood-borne cancer cells is } \\
\text { recognised by FKN expressec } \\
\text { on endothelium of bone } \\
\text { marrow to mediate cancer cell } \\
\text { homing to bone. }\end{array}$ \\
\hline
\end{tabular}




\begin{tabular}{|c|c|c|c|c|c|}
\hline & & & & $\begin{array}{l}\text { the bone marrow compared to wild type animals. In } \\
\text { comparison, no difference in metastasis to adrenal } \\
\text { gland was detected between the two groups. } \\
\text { Elegant experiments examined the effect of } \\
\text { transfecting poorly bone-metastatic MDA-MB-436 } \\
\text { cells with either fully functional CX }{ }_{3} \mathrm{CR} 1 \text {, or one of } \\
\text { two partially functional mutants. Animal experiments } \\
\text { then allowed examination of function at different time } \\
\text { points post-innoculation. Results provided strong } \\
\text { support for a role of CX }{ }_{3} \mathrm{CR} 1 \text { in early adhesion to } \\
\text { bone marrow endothelium and overall, } \mathrm{CX}_{3} \mathrm{CR} \\
\text { conferred the cells with } 3 \text { times greater ability to } \\
\text { form bone metastases }\end{array}$ & \\
\hline $\begin{array}{l}\text { Lau et al., } \\
2013 \text { [27] }\end{array}$ & $\begin{array}{l}\text { Enpp1 } \\
\text { Ectoenzyme } \\
\text { ectonucleotide } \\
\text { pyrophosphatase / } \\
\text { phosphodiesterase } \\
1\end{array}$ & $\begin{array}{l}\text { Regulated bone } \\
\text { mineralization } \\
\text { and osteoblast } \\
\text { differentiation; } \\
\text { modulates insulin } \\
\text { signalling. } \\
\text { Regulates } \\
\text { extracellular PPi } \\
\text { levels }\end{array}$ & $\begin{array}{l}\text { Mineralising } \\
\text { protein }\end{array}$ & $\begin{array}{l}\text { This study builds on the previous paper from this } \\
\text { group, Lau et al (2009). Enpp1expression was shown } \\
\text { to be increased in bone seeking murine (NT2.5) and } \\
\text { human breast cancer cell population (MDA-MB- } \\
\text { 231/MDA-MB-468) using quantitative PCR, western } \\
\text { blotting and immunohistochemical analysis. Further, } \\
\text { Enpp1 mRNA and protein were increased in primary } \\
\text { human breast cancers in comparison to normal } \\
\text { breast epithelium with highest levels in bone }\end{array}$ & $\begin{array}{l}\text { Transfection of Enpp1 cDNA } \\
\text { into MDA-MB-231 cells } \\
\text { showed no change in the } \\
\text { occurrence of bone metastasis } \\
\text { compared to the control as } \\
\text { parental cells also produce } \\
\text { bone metastases in all cases, } \\
\text { though there was increased } \\
\text { bone destruction and }\end{array}$ \\
\hline
\end{tabular}




\begin{tabular}{|c|c|c|c|c|c|}
\hline & & & & $\begin{array}{l}\text { metastases. } \\
\text { Increased expression of Enpp1 by MDA-MB-231 } \\
\text { cells resulted in more rapid progression of bone } \\
\text { metastases }\end{array}$ & $\begin{array}{l}\text { progression of disease } \\
\text { The paper does not investigate } \\
\text { potential function of Enpp1 in } \\
\text { establishment or progression } \\
\text { of bone metastases, but } \\
\text { putative mechanisms are } \\
\text { suggested. }\end{array}$ \\
\hline $\begin{array}{l}\text { Croset et al., } \\
2014 \text { [28] }\end{array}$ & TWIST1 & $\begin{array}{l}\text { Involved in } \\
\text { regulation of } \\
\text { organogenesis } \\
\text { and plays } \\
\text { important role in } \\
\text { bone formation. A } \\
\text { key regulator of } \\
\text { epithelial- } \\
\text { mesenchymal } \\
\text { transition (EMT) } \\
\text { in tumour } \\
\text { progression }\end{array}$ & $\begin{array}{l}\text { Transcription } \\
\text { factor }\end{array}$ & $\begin{array}{l}\text { TWIST1 expression in bone tropic MDA-MB- } \\
\text { 231/BO2 caused quicker bone metastasis and } \\
\text { increased osteolytic lesion when inoculated into } \\
\text { mice. } \\
\text { Preservation of bone tropism of MDA-MB-231/BO2 } \\
\text { cells was demonstrated with TWIST1 expression as } \\
\text { no evidence of metastasis was found organs other } \\
\text { than bone. } \\
\text { Significant reduction in incidence and extent of } \\
\text { tumour cell colonies in bone marrow was observed } \\
\text { when miR-10b (induced by TWIST1) was silenced. }\end{array}$ & $\begin{array}{l}\text { TWIST1 is shown to enhance } \\
\text { bone metastatic progression in } \\
\text { breast cancer cells that have } \\
\text { pre-existing osteotropism. } \\
\text { Hence a promoter rather than } \\
\text { an initiator of osteolytic } \\
\text { metastasis is indicated. }\end{array}$ \\
\hline
\end{tabular}


Fig.1 PRISMA flow-diagram of search results and exclusion process, after Moher et al [15]

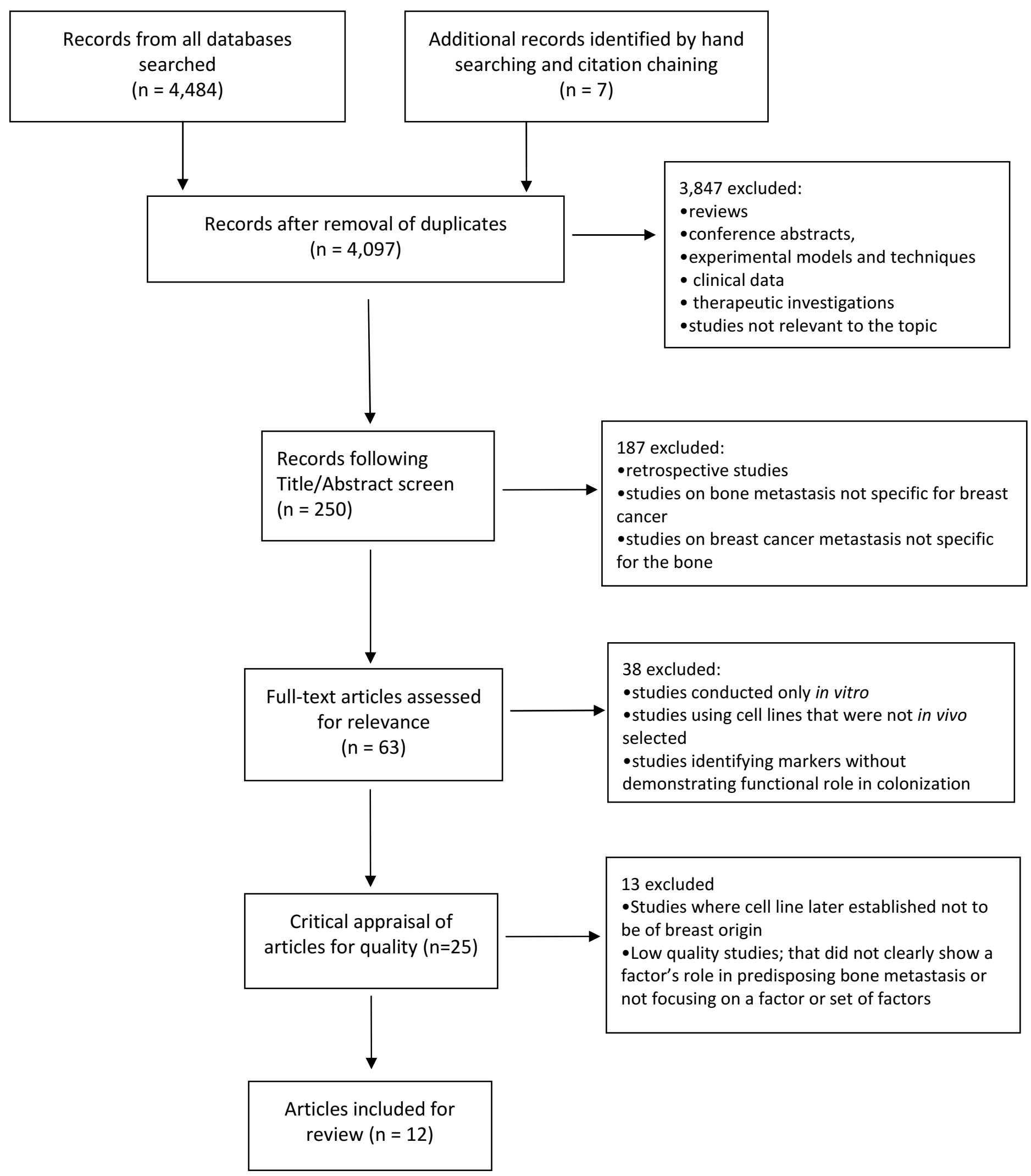


Fig.2 Functional roles of identified factors and possible molecular mechanisms involved in bone metastasis

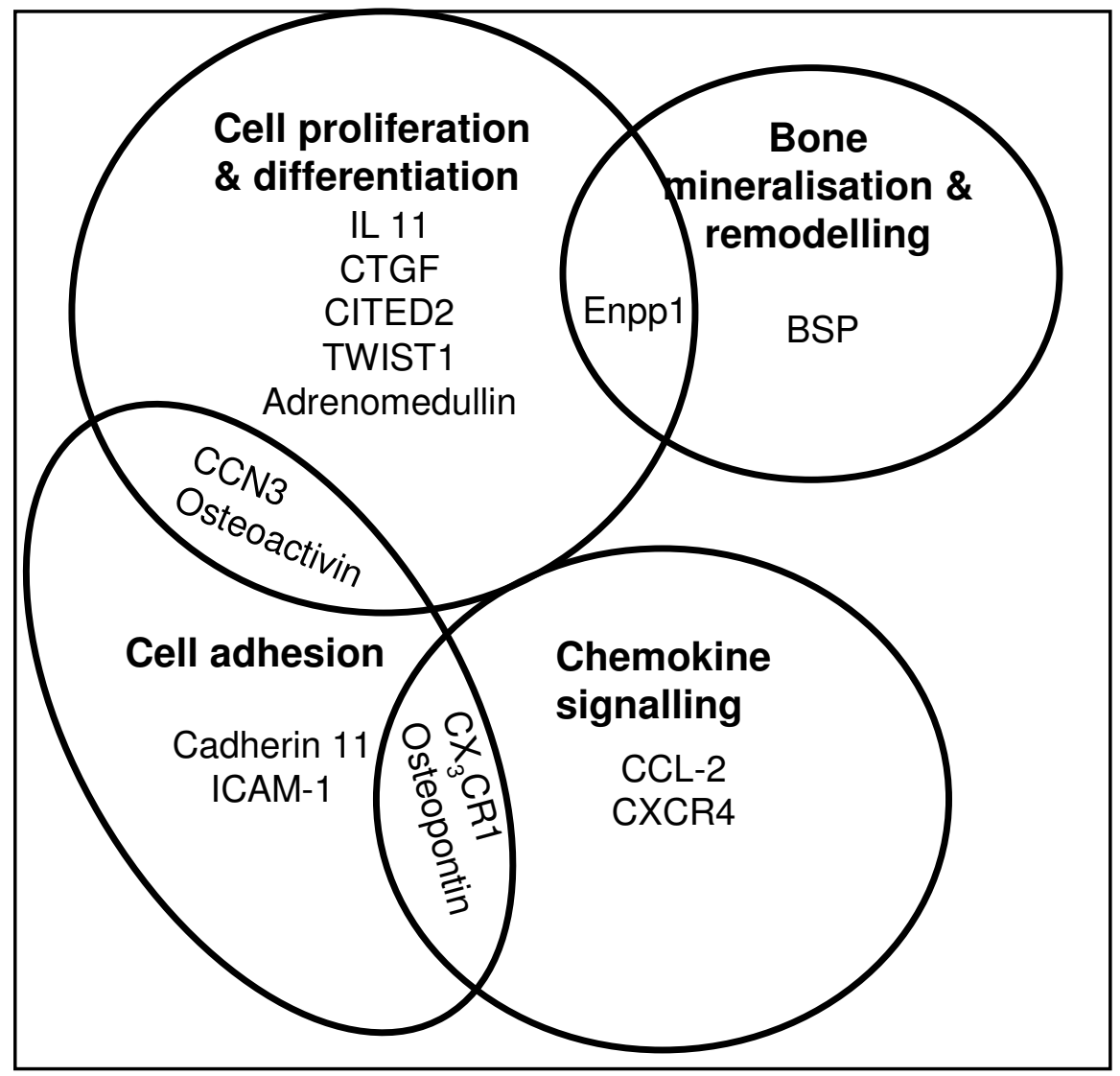




\begin{tabular}{|c|c|c|c|c|c|}
\hline $\begin{array}{l}\text { Siclari et al., } \\
2014 \text { [29] }\end{array}$ & Adrenomedullin, AM & $\begin{array}{l}\text { Widespread } \\
\text { homeostatic } \\
\text { function including } \\
\text { vasodilation, } \\
\text { angiogenesis, } \\
\text { hormone } \\
\text { secretion and cell } \\
\text { proliferation } \\
\text { Stimulates } \\
\text { osteoblast } \\
\text { proliferation }\end{array}$ & $\begin{array}{l}\text { Signalling } \\
\text { protein/hormone }\end{array}$ & $\begin{array}{l}\text { Adrenomedullin expression was positive in majority } \\
\text { of osteolytic breast cancer cell lines. } \\
\text { Nude mice inoculation of MDA-MB-231 cells with } \\
\text { fivefold over-expression of adrenomedullin mRNA } \\
\text { induced significantly increased osteolytic metastasis } \\
\text { and reduced survival when compared to control or } \\
\text { parental cells. } \\
\text { RANKL, produced by osteoblasts for osteoclast } \\
\text { activation, was inhibited with addition of } \\
\text { adrenomedullin antagonist to ex vivo breast cancer } \\
\text { cell-bone co-culture model. }\end{array}$ & $\begin{array}{l}\text { Adrenomedullin, found in } \\
\text { normal tissue is shown to play } \\
\text { a role in enhancing osteolytic } \\
\text { metastasis when over- } \\
\text { expressed in breast cancer } \\
\text { cells. Its inhibition resulted in } \\
\text { reduced osteoclast activity due } \\
\text { to RANKL blockade suggesting } \\
\text { a potential therapeutic target } \\
\text { against bone metastasis. }\end{array}$ \\
\hline
\end{tabular}

